\title{
Life cycle environmental impacts of advanced wastewater treatment techniques for removal of pharmaceuticals and personal care products (PPCPs)
}

DOI:

10.1016/j.jenvman.2018.03.047

\section{Document Version}

Accepted author manuscript

Link to publication record in Manchester Research Explorer

Citation for published version (APA):

Zepon Tarpani, R. R., \& Azapagic, A. (2018). Life cycle environmental impacts of advanced wastewater treatment techniques for removal of pharmaceuticals and personal care products (PPCPs). Journal of Environmental Management, 215, 258-272. https://doi.org/10.1016/j.jenvman.2018.03.047

Published in:

Journal of Environmental Management

\section{Citing this paper}

Please note that where the full-text provided on Manchester Research Explorer is the Author Accepted Manuscript or Proof version this may differ from the final Published version. If citing, it is advised that you check and use the publisher's definitive version.

\section{General rights}

Copyright and moral rights for the publications made accessible in the Research Explorer are retained by the authors and/or other copyright owners and it is a condition of accessing publications that users recognise and abide by the legal requirements associated with these rights.

\section{Takedown policy}

If you believe that this document breaches copyright please refer to the University of Manchester's Takedown Procedures [http://man.ac.uk/04Y6Bo] or contact uml.scholarlycommunications@manchester.ac.uk providing relevant details, so we can investigate your claim.

\section{OPEN ACCESS}




\title{
Life cycle environmental impacts of advanced wastewater treatment techniques for removal of pharmaceuticals and personal care products (PPCPs)
}

\author{
Raphael Ricardo Zepon Tarpani and Adisa Azapagic*
}

School of Chemical Engineering and Analytical Science, Room C16, The Mill, Sackville Street, The University of Manchester, Manchester M13 9PL, UK. Phone: +44 (0) 1613064380.

*Corresponding author: adisa.azapagic@ manchester.ac.uk

\begin{abstract}
Pharmaceutical and personal care products (PPCPs) are of increasing interest because of their ecotoxicological properties and environmental impacts. Wastewater treatment plants (WWTPs) are the main pathway for their release into freshwaters due to the inefficiency of conventional WWTPs in removing many of these contaminants from effluents. Therefore, different advanced effluent treatment techniques have been proposed for their treatment. However, it is not known at present how effective these treatment methods are and whether on a life cycle basis they cause other environmental impacts which may outweigh the benefits of the treatment. In an effort to provide an insight into this question, this paper considers life cycle environmental impacts of the following advanced treatment techniques aimed at reducing freshwater ecotoxicity potential of PPCPs: granular activated carbon (GAC), nanofiltration (NF), solar photo-Fenton (SPF) and ozonation. The results suggest that on average NF has the lowest impacts for 13 out of 18 categories considered. GAC is the best alternative for five impacts, including metals and water depletion, but it has the highest marine eutrophication. SPF and ozonation are the least sustainable for eight impacts, including ecotoxicity and climate change. GAC and NF are also more efficient in treating heavy metals while avoiding generation of harmful by-products during the treatment, thus being more suitable for potable reuse of wastewater. However, releasing the effluent without advanced treatment to agricultural land achieves a much higher reduction of freshwater ecotoxicity than treating it by any of the advanced treatments and releasing to the environment. Therefore, the use of advanced effluent treatment for agricultural purposes is not recommended.
\end{abstract}

Keywords: advanced wastewater treatment; ecotoxicity; life cycle assessment; pharmaceutical and personal care products; wastewater reuse

\section{Introduction}

Ageing population, increasing urbanisation, growing per-capita income and other factors have led to a significant increase in the consumption of pharmaceutical and personal care products (PPCPs) and this trend is expected to continue in the future (Hill \& Chu 2009, Lyons 2014, ter Laak et al. 2010, WHO 2004). Over 3,000 chemicals are used in the production of PPCPs (Daughton 2004) and they eventually reach the environment. One of the main pathways for this are wastewater treatment plants (WWTPs) (Celle-Jeanton et al. 2014, Heberer 2002, Onesios et al. 2009). This is due to the inefficiency of conventional plants in removing many PPCPs as they are designed to treat biodegradable, non-polar and large molecules, as opposed to small molecules and polar tendency of PPCP substances (Daughton 2001, Ratola et al. 2012, Richardson et al. 2005, Suárez et al. 2008). Additionally, several metabolites and transformation products are also expected to form in WWPT effluents alongside parent compounds as a result of various chemical reactions during the treatment (Farré et al. 2008, Quintana et al. 2005, Schuman 2008).

However, despite their widespread presence in the environment, often at notable concentrations (Carmona et al. 2014, Hughes et al. 2013, Kolpin et al. 2002), relatively little is known about their ecotoxicological effects (Boxall 2004, Carlsson et al. 2006, Fick et al. 2009, Jones-Lepp \& Stevens 2007, Khetan \& Collins 2007). To address the emerging concerns related to the impacts of these contaminants on the environment (Blasco \& Delvalls 2008, Cleuvers 2004, Fedorenkova et al. 
2010, Fent et al. 2006), legislation that requires their removal from WWTP effluents is currently being developed in Europe (Eggen et al. 2014, European commission 2015). Thus, it is necessary to consider possible advanced treatment options that could help reduce their release into the environment (Bui et al. 2016). A further motivation for considering such options is that water will become increasingly scarce in many world regions and wastewater reuse is being advocated as an option for increasing its availability (Miller 2006, Rodriguez et al. 2009, Urkiaga et al. 2006). Thereby, regulations towards emerging contaminants are under discussion to ensure safer wastewater reuse (Dalahmeh \& Baresel 2014, EPA 2012, Hanjra et al. 2012). To this end, some of the advanced effluent techniques are capable of not only removing PPCPs but could also enable reuse of water, either for irrigation or drinking (Bixio et al. 2008, CDPH 2009, Tchobanoglous et al. 2011).

At present, however, it is not known how environmentally effective different advanced treatment methods are in reducing the ecotoxicity impacts of PPCP compounds and if, by doing so, they increase the ecotoxicity potential elsewhere in the life cycle or cause other environmental impacts (Kärrman 2001, Muga \& Mihelcic 2008, Pasqualino et al. 2011, Tangsubkul et al. 2005). In an attempt to inform this debate, this paper considers life cycle environmental impacts of the following advanced treatment methods: granular activated carbon (GAC), nanofiltration (NF), solar photoFenton (SPF) and ozonation. These methods have been chosen for consideration because they are either already well established (the first two) or are most promising techniques (the last two) for removal of PPCPs.

As far as the authors are aware, this is the first study of its kind, providing a comprehensive quantitative comparison of these methods for a range of operating parameters typically found in WWTPs. Furthermore, no other studies considered the ecotoxicity potential of the PPCP compounds when released to freshwaters or used for agricultural purposes without advanced treatment in comparison with the ecotoxicity potential when treated in advanced treatment systems.

\section{Methods}

Life cycle assessment (LCA) has been used as a tool to estimate life cycle impacts of the chosen treatment methods following the ISO 14040 methodology (ISO 2006). The next sections detail the goal and scope together with the assumptions and data used in the study.

\subsection{Goal and scope of the study}

The goal of the study was to estimate and compare life cycle environmental impacts of the four advanced techniques - GAC, NF, SPF and ozonation - for the treatment of PPCPs. A further goal was to estimate the ecotoxicity of PPCPs in the effluent after advanced treatment and compare it to the equivalent impact of the effluent from conventional WWTPs without advanced treatment. The following nine PPCPs were chosen for consideration, spanning five product categories:

- analgesics: diclofenac and ibuprofen;

- antibiotics: erythromycin, trimethoprim and sulfamethoxazole;

- psychiatric drugs: carbamazepine;

- hormones: estrone and 17ß-estradiol; and

- antiseptics: triclosan.

These substances were selected due to:

- their potential to cause undesired ecotoxicological effects;

- higher concentration and frequency of detection in effluents of conventional WWTPs; and

- availability of ecotoxicological data.

The system and the system boundaries are outlined in Figure 1. As indicated in the figure, the scope of the study was from 'cradle to grave', encompassing construction, operation and decommissioning of the treatment plant. The advanced effluent treatment plant was assumed to be 
coupled with a conventional WWTP, which includes a membrane bioreactor (MBR) as part of the secondary activated sludge treatment. The MBR is needed to enable a more efficient operation of the advanced treatment plant because it reduces total suspended solids and biochemical oxygen demand more efficiently than conventional biological treatment (Alturki et al. 2010, Cases et al. 2011, Laera et al. 2012, Snyder et al. 2007). The assumed capacity of the MBR plant was 64,000 $\mathrm{m}^{3} / \mathrm{d}$, corresponding to the average capacity of WWTPs in the UK (DEFRA 2012). Furthermore, it was assumed that the advanced treatment methods are capable of treating wastewater to nearpotable water standards since they are controlled for $\mathrm{pH}$, pathogens, hardness and heavy metals.

The functional unit was defined as the "treatment of $1,000 \mathrm{~m}^{3}$ of effluent from conventional wastewater treatment". The treatment facility was assumed to be located in the UK. The lifetime of the plants was assumed at 60 years (Pasqualino et al. 2009), with periodic replacements of equipment, as detailed further below.

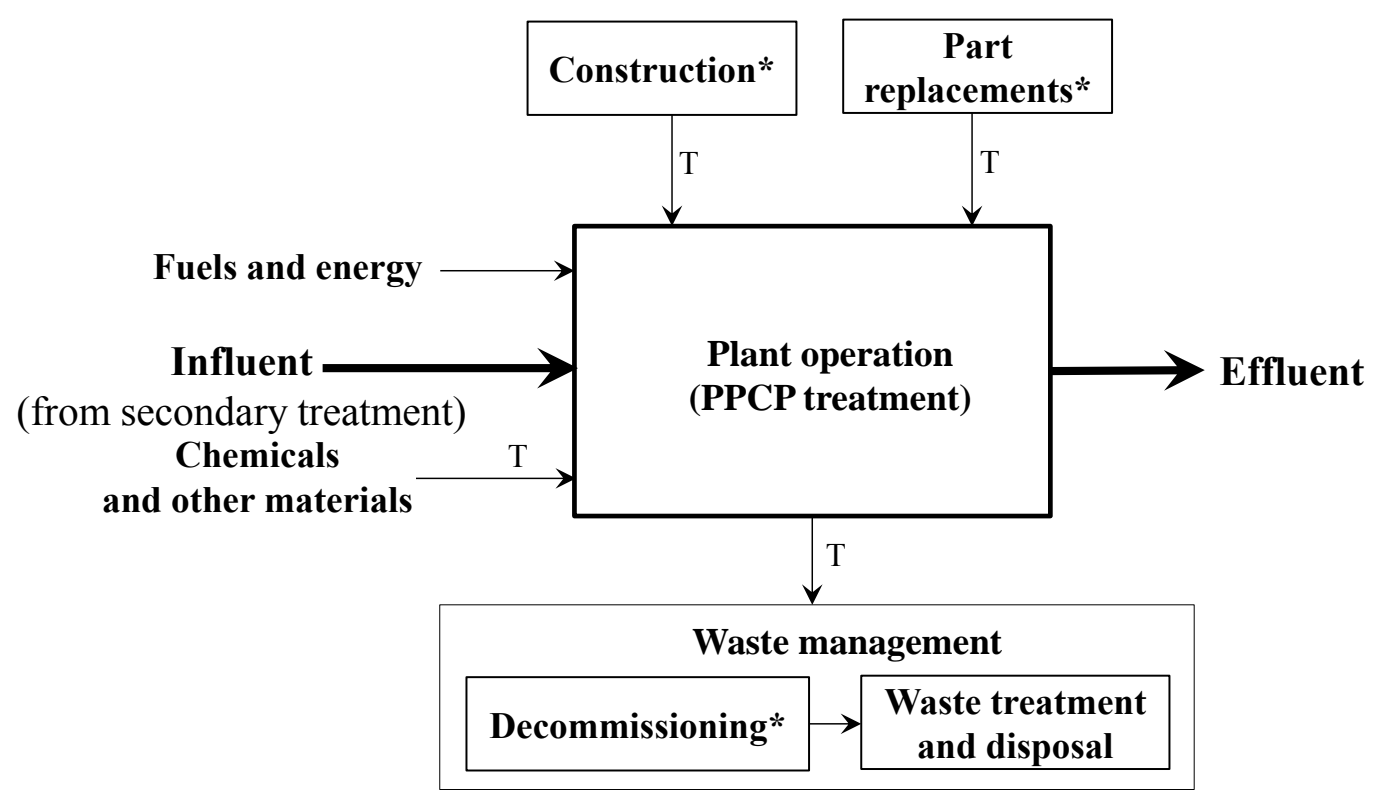

Figure 1 - System boundaries and life cycle stages of the advanced effluent treatments techniques considered in the study (*Excluded for ozonation due to a lack of data. T: transport)

\subsection{Inventory data}

The inventory data were sourced from the literature and own estimates as detailed in the next sections. Industry data were not available as the removal of PPCP compounds is still not carried out by the water industry due to a lack of legislation. The life cycle data were taken from Ecoinvent 2.2 (Frischknecht et al. 2004) and the UK electricity grid updated to the year 2016 (BEIS 2016).

The following sections give a brief description of the advanced treatment methods considered, followed by an overview of the estimation of the operating parameters.

\subsubsection{Overview of advanced treatment techniques}

\subsubsection{Granular activated carbon}

GAC treatment removes PPCP compounds by physical adsorption onto the GAC bed and to a lesser extent through biodegradation, thus avoiding generation of harmful reaction by-products. Moreover, a high removal of metals is expected (Fu \& Wang 2011, Goel et al. 2005). After a certain time in use, the bed needs to be regenerated or replaced (Figure 2). Hence, the key influencing parameters are the amount of fresh GAC required for the treatment and the number of regeneration cycles before the bed needs to be replaced. These were estimated according to the method detailed in section 2.2.2.1. 


\subsubsection{Nanofiltration}

NF uses membranes to remove PPCP compounds from the effluent (Figure 2). First, the wastewater is passed through pre-filters under high pressure to remove particles and then through the membranes with the pore sizes of 0.1 to $1.0 \mathrm{~nm}$, separating the influx into the permeate (treated effluent) and concentrate (contaminants), assumed to be recycled back to the treatment. The primary removal of contaminants is through physical sieving, followed by adsorption and electrostatic repulsion, which can achieve a high removal efficiency of heavy metals and avoid the formation of by-products (Bellona et al. 2004, Bolong et al. 2009, Fu \& Wang 2011). NF units are designed in a modular fashion, with the total number of modules varying according to the influent flow and the desired quality of effluent. One important factor in NF treatments is membrane fouling, causing a pressure drop and requiring more electricity to maintain the flux. When the pressure drop becomes too large, the units need to be cleaned using chemical agents (Al-Amoudi \& Lovitt 2007, Simon et al. 2013). Therefore, the key operating parameters that need to be considered for NF are electricity consumption and the usage of cleaning agents. The former includes electricity for pre-filtration and NF, high-pressure pumping, water heating during winter months and the lighting of the building. The type of chemical agents used depends on the influent composition, filtration pressure and membrane properties (Bruggen et al. 2008, Yoon et al. 2006). The data for NF were taken from real facilities in Canada and France (Bonton et al. 2012, Cyna et al. 2002), as detailed in section 2.2.4.

\subsubsection{Solar photo-Fenton}

The solar-photo Fenton (SPF) technique is an advanced oxidation process known for simple operation and high efficiency in treating most organic contaminants. The process consists of adding a catalyst and hydrogen peroxide to the influent which is then passed through reactors irradiated by solar light to generate $\mathrm{OH}$ radicals and oxidise PPCPs (Figure 2). To increase the treatment efficiency, the influent should be kept at low $\mathrm{pH}$, followed by its neutralisation before the discharge into the environment (Muñoz et al. 2007). Hence, the main parameters that need to be considered in this treatment are the amounts of the catalyst and hydrogen peroxide. These are still subject of ongoing research as SPF is still under development, but some pilot-plant data are available (Klamerth 2011, Lofrano 2012, Ribeiro et al. 2015) which were considered here. These and other inventory data for SPF can be found in section 2.2.4.

\subsubsection{Ozonation}

The ozonation treatment (disinfection), works through direct and indirect reactions of PPCPs with $\mathrm{OH}$ radicals generated by ozone decomposition in the contactors (Figure 2). This method can achieve a good removal of metals but can also generate harmful by-products (Margot et al. 2013, Tripathi \& Tripathi 2011, Westerhoff et al. 2005). The overall treatment efficiency is directly dependent on the influent $\mathrm{pH}$, contact time and organic matter content. After the treatment, the effluent is balanced by the addition of sodium hydroxide. The ozone can be generated either from liquid oxygen or air, with the latter mainly used at large-scale facilities; both methods have significant electricity requirements (Kim \& Tanaka 2011, Wang et al. 2005). The main parameters that need to be considered in the design of ozonation units are the amount of ozone required for efficient treatment and electricity consumption. Their estimation is discussed in section 2.2.2.2. 


\subsubsection{Estimation of operating parameters for GAC and ozonation}

As mentioned above, data for the operating parameters for NF and SPF were taken from the literature and are discussed in section 2.2.4. However, for GAC and ozonation data for the key operating parameters were not available and had to be estimated as detailed below.

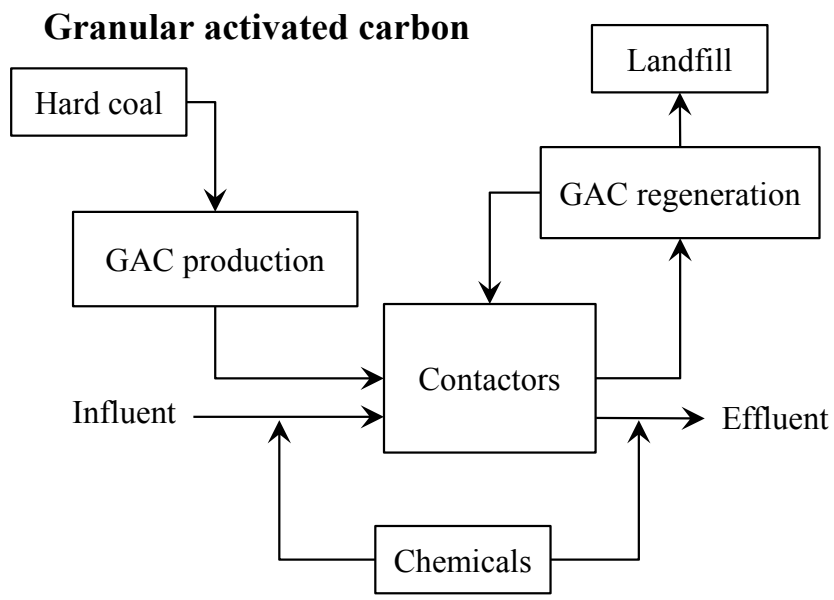

\section{Nanofiltration}

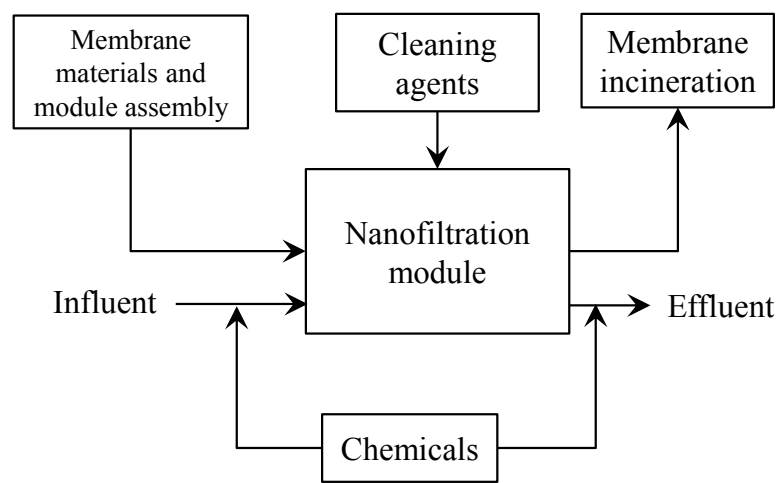

Solar photo-Fenton

Ozonation
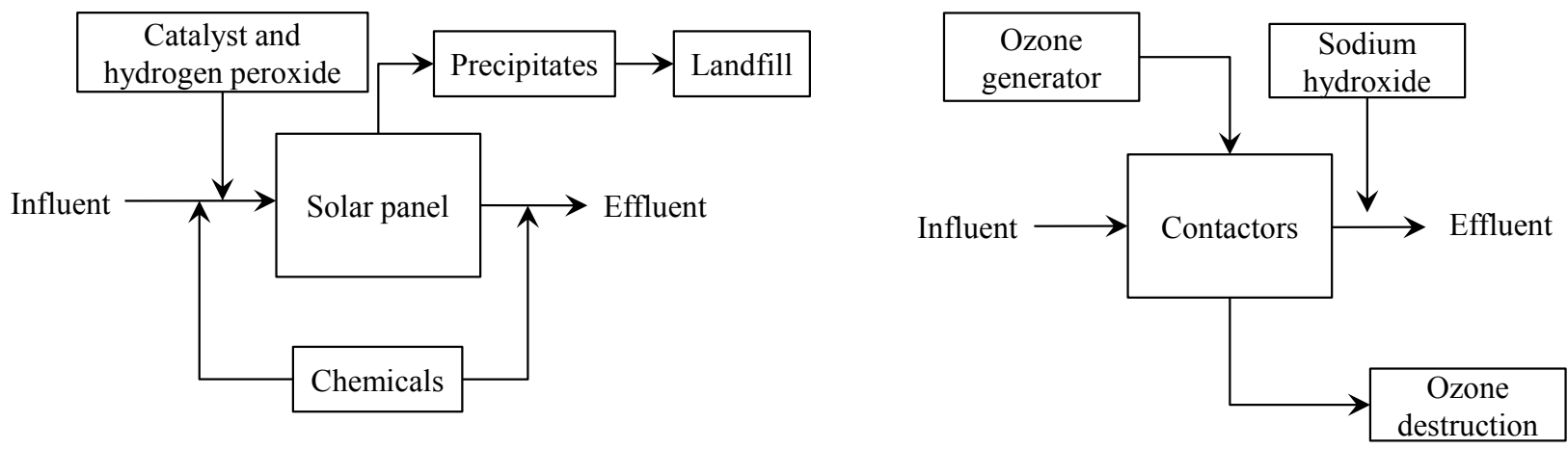

Figure 2 An overview of the advanced PPCP treatment methods considered in the study.

\subsubsection{Granular activated carbon}

The key operating parameters for GAC - the amount of fresh GAC and the number of regeneration cycles before the bed has to be replaced - were estimated based on two criteria commonly considered in the design of GAC: empty-bed contact time (EBCT) and the bed service time (Bayer et al. 2005, Creek \& Davidson 2000, Reed et al. 1996). The initial amount of fresh granular activated carbon was estimated for different EBCTs, as follows:

$\mathrm{V}_{\mathrm{GAC}}=\mathrm{EBCT} \times \mathrm{Q}_{\mathrm{inf}}$

$\left(\mathrm{m}^{3}\right)$

where:

$\mathrm{V}_{\mathrm{GAC}} \quad$ volume of granular activated carbon in the bed $\left(\mathrm{m}^{3}\right)$

EBCT empty-bed contact time ( $\mathrm{min})$

Qinf influent flow to be treated $\left(\mathrm{m}^{3} / \mathrm{min}\right)$.

The maximum number of bed regenerations was fixed at 10 to ensure the bed's initial characteristics were maintained, with $\sim 50 \%$ of the bed regenerated less than five times. This is based on Bayer et al. (2005), who suggested 7-12 refills for an efficient operation of the GAC treatment. Consequently, the total number of bed replacements $\left(\mathrm{N}_{\mathrm{br}}\right)$ over the lifespan of the unit (60 years) is defined as follows: 
$\mathrm{N}_{\mathrm{BR}}=\mathrm{T}_{\text {treatment }} /\left(\mathrm{n}_{\max } \mathrm{t}_{\mathrm{GAC}}\right)$

where:

$\mathrm{N}_{\mathrm{BR}} \quad$ total number of bed replacements over the lifespan of 60 years (-)

$\mathrm{T}_{\text {treatment }} \quad$ treatment time (days)

$\mathrm{n}_{\max } \quad$ maximum number of bed regenerations before replacement (10)

$\mathrm{t}_{\mathrm{GAC}} \quad$ bed service time (days).

The amount of fresh and regenerated GAC was then calculated by adapting the method proposed by Clements (2002):

$\mathrm{F}_{\mathrm{GAC}}=\mathrm{m}_{\mathrm{GAC}}\left[1+\mathrm{N}_{\mathrm{BR}}+\mathrm{m}_{\text {loss }}\left(\mathrm{n}_{\mathrm{r}}+\mathrm{N}_{\mathrm{BR}} \mathrm{n}_{\max }\right)\right] \quad(\mathrm{kg})$

$\mathrm{R}_{\mathrm{GAC}}=\mathrm{m}_{\mathrm{GAC}}\left(\mathrm{n}_{\mathrm{r}}+\mathrm{N}_{\mathrm{BR}} \mathrm{n}_{\max }\right) \quad(\mathrm{kg})$

where:

$\mathrm{F}_{\mathrm{GAC}} \quad$ amount of fresh GAC needed for the treatment $(\mathrm{kg})$

$\mathrm{m}_{\mathrm{GAC}} \quad$ amount of granular activated carbon in the bed $(\mathrm{kg})$

$\mathrm{m}_{\text {loss }} \quad$ percentage of GAC lost during regeneration (\%)

$\mathrm{n}_{\mathrm{r}} \quad$ number of bed regenerations after the previous bed replacement (-)

$\mathrm{R}_{\mathrm{GAC}} \quad$ amount of regenerated GAC $(\mathrm{kg})$.

The assumptions for the variables in eqns. (1)-(4) are summarised in Table 1. As can be seen, three different EBCTs and bed service times were considered, based on the range of values reported for large GAC treatment facilities (Bayer et al. 2005, Clements 2002, Creek et al. 2001, Reungoat et al. 2011). The trends for the fresh and regenerated GAC requirements according to the different bed service times are given in Figure 3; the actual values can be found in Table 1. As expected, the required amount of GAC decreases with increasing the bed service time. These results were used in LCA to determine the influence on the environmental impacts of the variation in the key parameters.

Table 1 Operating parameters for GAC (eqns. (1)-(4)) and ozonation (eqns. (5)-(6)) per 1,000 $\mathrm{m}^{3}$ of wastewater

\begin{tabular}{|c|c|c|c|c|c|c|c|c|c|}
\hline \multirow{4}{*}{ GAC } & $\begin{array}{c}\text { EBCT } \\
(\min )\end{array}$ & $\begin{array}{c}\mathbf{Q}_{\text {inf }} \\
\left(\mathrm{m}^{3} / \mathrm{h}\right)\end{array}$ & $\begin{array}{l}\mathbf{V}_{\mathbf{G A C}} \\
\left(\mathrm{m}^{3}\right)\end{array}$ & $\begin{array}{c}\mathbf{m}_{\mathrm{GAC}}{ }^{\mathbf{a}} \\
(\mathrm{kg})\end{array}$ & $\begin{array}{l}\mathbf{t}_{\mathrm{GAC}}{ }^{\mathbf{b}} \\
(\mathrm{d})\end{array}$ & $\mathbf{N}_{\mathrm{BR}}^{\mathrm{c}}$ & $\mathbf{n}_{\mathbf{r}}$ & $\begin{array}{c}\text { Fresh } \\
\text { GAC }^{\text {d }} \\
(\mathrm{kg})\end{array}$ & $\begin{array}{c}\text { Regenerated } \\
\text { GAC }(\mathrm{kg})\end{array}$ \\
\hline & 20 & & 889 & 501,396 & 330 & 6 & 6 & $6,818,986$ & $33,092,136$ \\
\hline & 30 & 2,667 & 1,334 & 752,094 & 220 & 9 & 9 & $14,966,671$ & $74,457,306$ \\
\hline & 40 & & 1,778 & $1,002,792$ & 110 & 19 & 9 & $40,011,401$ & $199,555,608$ \\
\hline \multirow{4}{*}{ Ozonation } & $\begin{array}{c}\mathbf{T} \\
\left(\mathrm{kg} / \mathrm{m}^{3}\right)\end{array}$ & $\begin{array}{l}\text { TE } \\
(\%)\end{array}$ & $\begin{array}{c}\text { D }_{\text {ozone }} \\
\left(\mathrm{kg} / \mathrm{m}^{3}\right)\end{array}$ & $\begin{array}{l}\mathbf{V}_{\text {inf }} \\
\left(\mathrm{m}^{3}\right)\end{array}$ & $\begin{array}{c}\mathbf{E}_{\text {ozone }} \\
\left(\mathrm{kWh} / \mathrm{kg}_{\text {ozone }}\right)\end{array}$ & \multicolumn{3}{|c|}{$\begin{array}{c}\mathbf{E}_{\text {ozonation }} \\
(\mathrm{kWh})\end{array}$} & \\
\hline & 0.004 & 75 & 0.005 & \multirow{3}{*}{1,000} & \multirow{3}{*}{16.5} & \multicolumn{3}{|c|}{88} & \\
\hline & 0.023 & 50 & 0.046 & & & \multirow{2}{*}{\multicolumn{3}{|c|}{$\begin{array}{c}759 \\
2772\end{array}$}} & \\
\hline & 0.042 & 25 & 0.168 & & & & & & \\
\hline
\end{tabular}

${ }^{\mathrm{a}} \mathrm{GAC}$ density: $564 \mathrm{~kg} / \mathrm{m}^{3}$.

${ }^{\mathrm{b}}$ Values from Figure 3.

${ }^{\mathrm{c}} \mathrm{n}_{\max }=10 ; \mathrm{T}_{\text {treatment }}: 21,900$ days (over the 60 year lifespan).

${ }^{\mathrm{d}} \mathrm{m}_{\text {loss }}=10 \%$ (Bayer et al. 2005).

\subsubsection{Ozonation}

As mentioned earlier, the main operating parameters that need to be considered for ozonation units are the amount of ozone required for efficient treatment and electricity consumption. The former can be calculated as (Wang et al. 2005):

$\mathrm{D}_{\text {ozone }}=\mathrm{T} \frac{100}{\mathrm{TE}} \quad(\mathrm{mg} / \mathrm{L})$ 
where:

Dozone $\quad$ applied ozone dosage $(\mathrm{mg} / \mathrm{L})$

$\mathrm{T} \quad$ transferred ozone dosage $(\mathrm{mg} / \mathrm{L})$

TE ozone transfer efficiency $(\%)$.

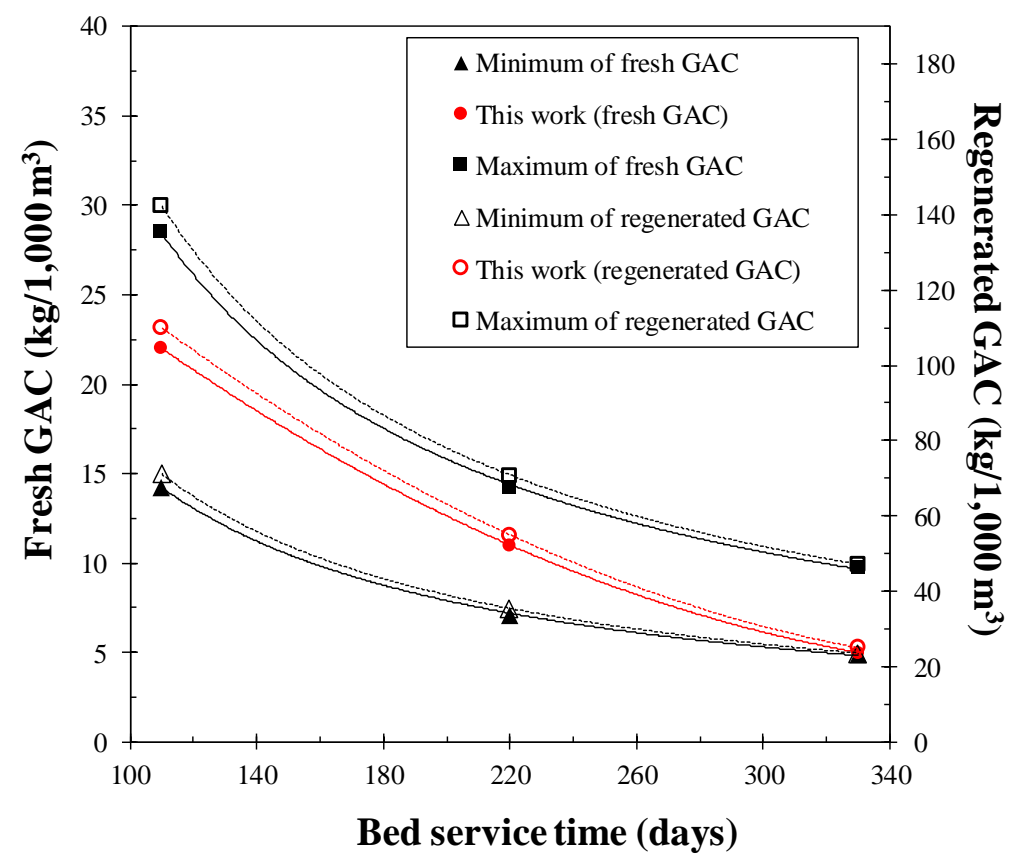

Figure 3 Estimated ranges of fresh and regenerated granular activated carbon for 1,000 $\mathrm{m}^{3}$ of wastewater treated (Black lines: ranges for different bed service times and empty-bed contact times. Red lines: ranges considered in this work. GAC lost during regeneration: $\mathrm{m}_{\mathrm{loss}}=10 \%$; GAC density: $564 \mathrm{~kg} / \mathrm{m}^{3}$.

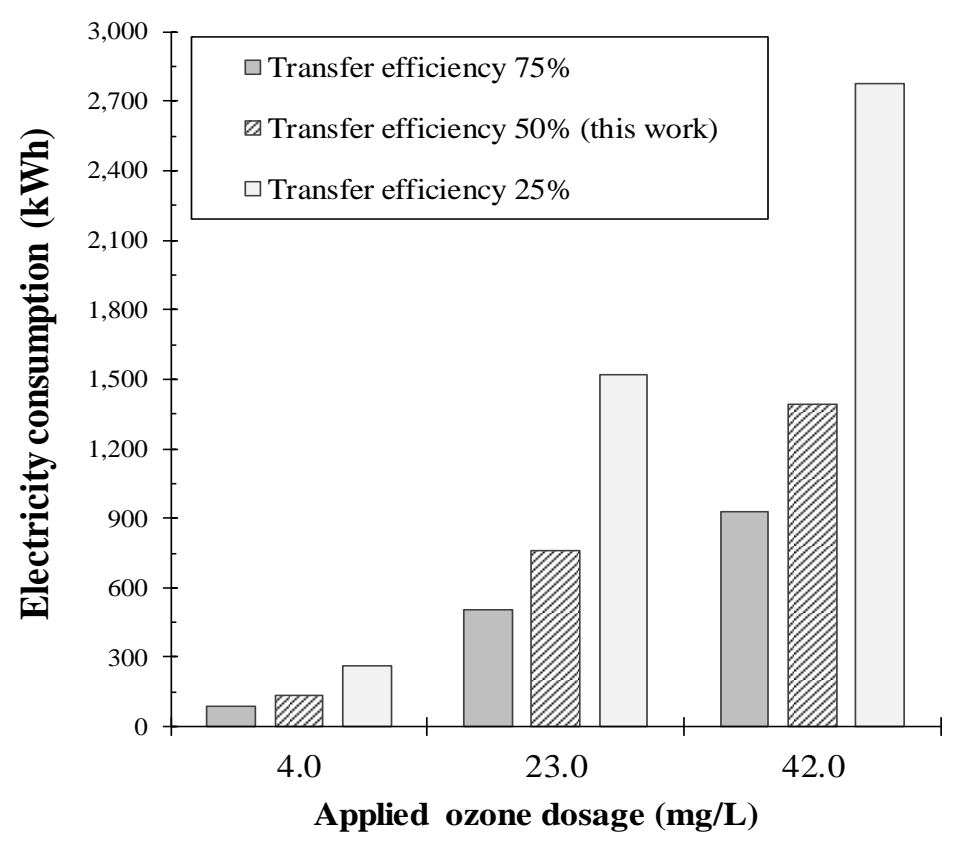

Figure 4 - Estimated electricity consumption per $1,000 \mathrm{~m}^{3}$ of wastewater for different ozone transfer efficiencies and applied ozone dosage (Transfer efficiency: 50\%).

The range of transferred ozone dosages and the transfer ozone efficiencies considered here can be found in Table 1. These values were chosen to match the ranges found in the literature for achieving higher final water quality from secondary effluents (Wang et al. 2005). 
The electricity consumption in the ozonation treatment was estimated as being directly proportional to the amount of wastewater treated and electricity consumption for ozone production, as follows:

$\mathrm{E}_{\text {ozonation }}=\mathrm{D}_{\text {ozone }} \mathrm{V}_{\text {inf }} \mathrm{E}_{\text {ozone }}$

where:

$\mathrm{E}_{\text {ozonation }} \quad$ electricity consumption for ozonation $(\mathrm{kWh})$

$\mathrm{D}_{\text {ozone }} \quad$ applied ozone dosage $\left(\mathrm{kg}_{\text {ozone }} / \mathrm{m}^{3}\right)$

$\mathrm{V}_{\text {inf }} \quad$ influent volume to be treated, i.e. the functional unit $\left(\mathrm{m}^{3}\right)$

$\mathrm{E}_{\mathrm{ozone}} \quad$ electricity consumption for ozone production $\left(\mathrm{kWh} / \mathrm{kg}_{\mathrm{ozone}}\right)$.

Based on the data in Table 1, the transferred ozone dosage (T) was estimated in the range from 4 to $42 \mathrm{mg} / \mathrm{L}$ (Burns et al. 2007, Petala et al. 2006, Tripathi \& Tripathi 2011, Wang et al. 2005). The average electricity consumption for ozone generation $\left(\mathrm{E}_{\mathrm{ozone}}\right)$ from the air was estimated at 16.5 $\mathrm{kWh} / \mathrm{kg}_{\text {ozone }}$ (Wang et al. 2005). Thus, the estimated electricity consumption for ozonation ( $\mathrm{E}_{\text {ozonation }}$ ) ranges from 90 to $2,780 \mathrm{kWh} / 1,000 \mathrm{~m}^{3}$ for the transfer efficiency TE between $25 \%$ and $75 \%$ (Figure 4). This variation is due to the strong dependence of the TE on the reactor type and size, influent composition and the required level of treatment (disinfection).

\subsubsection{Estimation of removal rates of target PPCPS}

The concentrations of PPCPs in the effluents of WWTPs vary greatly in the literature, as indicated in Table 2. To account for this variability, the mean concentrations of target PPCPs were considered here (also shown in Table 2), based on the measurements in WWTPs around the globe. A wide variation in the removal efficiencies of advanced treatment systems is also reported (Bellona et al. 2004, Delgado et al. 2012, Gogate \& Pandit 2004a,b; Tabe et al. 2009, Yoon et al. 2007, Yu et al. 2008), as they are heavily dependent on the influent composition and operating parameters. Nevertheless, the removal of the PPCPs using the advanced methods considered in this study is commonly reported to be greater than $65 \%$. For this reason, the following range of removal efficiencies is considered: $65 \%, 75 \%, 85 \%, 95 \%$ and $99 \%$.

Table 2 - Concentration of target PPCPs in secondary effluents from WWTP entering the advanced treatment systems

\begin{tabular}{|c|c|c|c|c|}
\hline \multirow{2}{*}{ Compound } & \multicolumn{3}{|c|}{ Concentration $(\mu \mathrm{g} / \mathrm{L})$} & \multirow{2}{*}{ Sources } \\
\hline & Minimun & Mean & Maximum & \\
\hline Diclofenac & 0.49 & 0.65 & 0.80 & Tarpani and Azapagic (2018), Verlicchi et al. (2012) \\
\hline Ibuprofen & 0.37 & 1.99 & 3.60 & Tarpani and Azapagic (2018), Verlicchi et al. (2012) \\
\hline Trimethoprim & 0.12 & 0.24 & 0.36 & Tarpani and Azapagic (2018), Verlicchi et al. (2012) \\
\hline Erythromycin & 0.73 & 0.75 & 0.77 & Verlicchi et al. (2012), Tarpani \& Azapagic 2018) \\
\hline Sulfamethoxazole & 0.06 & 0.17 & 0.28 & Tarpani and Azapagic (2018), Verlicchi et al. (2012) \\
\hline Carbamazepine & 0.99 & 1.02 & 1.04 & Tarpani and Azapagic (2018), Verlicchi et al. (2012) \\
\hline Estrone & 0.03 & 0.06 & 0.08 & Verlicchi et al. (2012), Tarpani and Azapagic (2018) \\
\hline $17 \beta$-Estradiol & 0.008 & 0.009 & 0.010 & Tarpani and Azapagic (2018), Verlicchi et al. (2012) \\
\hline Triclosan & 0.07 & 0.20 & 0.32 & Tarpani and Azapagic (2018), Verlicchi et al. (2012) \\
\hline
\end{tabular}




\subsubsection{Other inventory data}

The inventory data for the construction, operation and decommissioning of the advanced treatment plants over their lifespan are detailed in Table 3; further information can be found in Table S1 in SI. The data for GAC and NF are based on full-scale facilities treating 2,000 $\mathrm{m}^{3} / \mathrm{d}$ (Bonton et al. 2012) while for SPF, data from a pilot-scale study treating $7 \mathrm{~m}^{3} / \mathrm{d}$ were used (Muñoz 2006, Muñoz et al. 2007). Hence, it was necessary to scale up the plant to estimate the amount of materials used in the construction of an industrial-size plant. This was carried out by adapting the "economy of scale" relationship, used for the scaling of process plants costs (Coulson et al. 1993), as follows:

$\mathrm{C}_{2}=\mathrm{C}_{1}\left(\frac{\mathrm{c}_{2}}{\mathrm{c}_{1}}\right)^{0.6}$

where:

$\mathrm{C}_{1}$ and $\mathrm{C}_{2}$ material requirements for smaller and larger scale plants, respectively

$\mathrm{c}_{1}$ and $\mathrm{c}_{2} \quad$ respective treatment capacities

0.6 the "economy of scale" factor.

For ozonation, no construction or decommissioning data were available and these are thus excluded from consideration (see Figure 1).

Regarding the operating data, for each treatment method, minimum, mean and maximum values were considered for each key parameter discussed in section 2.2.1 (for details, see Table 3). The data for the GAC production and regeneration processes were based on Bayer et al. (2005) and Jeswani et al. (2015). The electricity consumption and the cleaning agents (ethylenediaminetetraacetic acid (EDTA) and sodium hydroxide) used in NF were based on the minimum and maximum values reported in Bonton et al. (2012) and Cyna et al. (2002). For SPF, the dosage of catalyst (iron salts) and hydrogen peroxide was based on the studies by Trovó et al. (2013), Ribeiro et al. (2015) and Klamerth (2011). The electricity consumption in SPF was excluded due to a lack of data. Sodium hydroxide used for alkalinity balancing in ozonation was estimated from Muñoz et al. (2007).

The plant parts, such as motors, pipes, pumps, solar panels and ozone diffusers, were assumed to be replaced every 10-15 years. After the end of their useful lifetime of 60 years, the plants were assumed to be decommissioned and waste treated using current waste management practices in the UK for recycling and landfilling of construction materials (BRE/DEFRA 2010). The systems were credited for the recycled materials. GAC was assumed to be landfilled after 10 regeneration cycles and NF membranes incinerated at the end of their lifetime of ten years.

\section{$2.3 \quad$ Impact assessment}

The ReCiPe 2008 method (Goedkoop et al. 2009) was used to estimate the environmental impacts of the advanced PPCP treatment options. All eighteen impacts included in ReCiPe are considered here as discussed in the next section. In addition, freshwater ecotoxicity potential of PPCP compounds was estimated using the USEtox methodology (Henderson et al. 2011, Rosenbaum et al. 2008) to find out if the treatment reduces the ecotoxicity associated with PPCPs on a life cycle basis. Gabi 6.0 (Thinkstep 2015) was used for LCA modelling and estimating the impacts.

\section{Results and discussion}

The LCA results are first presented for the mean operating parameters (see Table 3) for each impact in turn. The overview of these results is given in Figure 5 and Figure 6, where the error bars represent the results for the minimum and maximum values of the parameters, discussed in section 2.2.2. As can be seen from Figure 6, the majority of the impacts across all the treatment techniques are from the operation of the plants. 


\subsection{Environmental impacts}

\subsubsection{Climate change potential}

The results in Figure 5 suggest that GAC and SPF have a similar impact on climate change, with the mean values estimated at 252 and $249 \mathrm{~kg} \mathrm{CO}_{2}$ Equiv./1,000 $\mathrm{m}^{3}$, respectively. However, the best option is NF with $191 \mathrm{~kg} \mathrm{CO} 2$ Equiv. At $316 \mathrm{CO}_{2} \mathrm{~kg}$ Equiv./1,000 $\mathrm{m}^{3}$, ozonation is the worst alternative, with around $25 \%$ higher impact than GAC. For the latter, $41 \%$ of the impact is due to the production of fresh activated carbon and $26 \%$ due to the energy used for its regeneration, with the rest being due mostly to aluminium sulphate production. Since fresh GAC is imported from Germany, $4 \%$ of the impact is due to road transport.

In NF, $65 \%$ of the impact is from electricity generation and the remainder from the productions of liquid carbon dioxide and calcium hydroxide (used for fouling control and effluent balancing). For SPF half of the impact is due to hydrogen peroxide production and another $47 \%$ from other operational activities, with the rest being from transport. The majority of the climate change potential of ozonation is from electricity (71\%) with the rest being due to sodium hydroxide production.

\subsubsection{Resource depletion potential-fossil fuels and metals}

As can be seen in Figure 5, GAC and SPF have similar fossil resource depletion potentials (88 and $81.5 \mathrm{~kg}$ oil Equiv. $/ 1,000 \mathrm{~m}^{3}$, respectively) while ozonation has around $10 \%$ higher impact (97 $\mathrm{kg}$ oil Equiv.). For GAC, $50 \%$ of the impact is related to the production of fresh activated carbon, $24 \%$ to energy used for regeneration and 22\% to the treatment process (Figure 6). For NF and ozonation, electricity consumption is the main contributor to the depletion of fossil resources $(77 \%$ and $75 \%$, respectively).

The lowest metal depletion potential was found for GAC and NF (4.9 and 6.0 kg Fe Equiv./1,000 $\mathrm{m}^{3}$, respectively) and the highest for SPF (23.4 kg Fe Equiv.). For GAC, the credit for materials recycling after decommissioning reduces the impact by $10 \%$ and SPF in $16 \%$. For SPF, the majority of the impact is due to hydrogen peroxide (38\%), sodium hydroxide (29\%) and sulphuric acid $(21 \%)$.

\subsubsection{Water depletion potential}

The highest water consumption was found for ozonation, estimated at $1,230 \mathrm{~m}^{3}$ per $1,000 \mathrm{~m}^{3}$ of water treated (Figure 5). Therefore, more water is consumed along the life cycle than treated. A half of this is due to water consumption during electricity generation and another half from sodium hydroxide production. SPF is the second worst option with $1,080 \mathrm{~m}^{3} / 1,000 \mathrm{~m}^{3}$. By contrast, GAC and NF consume roughly three times less water.

\subsubsection{Ozone depletion potential}

$\mathrm{NF}$ is the best option for this impact, followed by GAC (10.2 and $16.2 \mathrm{mg}$ CFC-11 Equiv./1,000 m ${ }^{3}$, respectively). The highest impact is from the SPF treatment (23.8 mg CFC-11 Equiv./1,000 $\left.\mathrm{m}^{3}\right)$, the majority of which $(58 \%)$ is due to hydrogen peroxide production. The contribution of transport is also relevant for this treatment option (11\%). For ozonation, two thirds of the impact, estimated at $17 \mathrm{mg}$ CFC-11 Equiv./1,000 $\mathrm{m}^{3}$, originate from electricity generation and the rest from sodium hydroxide production.

\subsubsection{Eutrophication potential-freshwater and marine}

SPF has the highest freshwater eutrophication potential, equal to $0.16 \mathrm{~kg} \mathrm{P}$ Equiv. $/ 1,000 \mathrm{~m}^{3}$, with the main contributor $(\sim 56 \%)$ being phosphate emissions to freshwater related to sodium hydroxide production. The equivalent impact for the other treatment alternatives ranges from 0.03 to $0.11 \mathrm{~kg} \mathrm{P}$ Equiv. $/ 1,000 \mathrm{~m}^{3}$, almost exclusively due to the operation of the treatment facilities. 
GAC has the highest marine eutrophication potential, around $65 \%$ higher than the other three methods. Unlike other impacts, the contribution to this impact for GAC is dominated by disposal of activated carbon (57\%; see Figure 6), due to the organically-bound nitrogen.

\subsubsection{Acidification potential-terrestrial}

For this impact, $\mathrm{SPF}$ is the worst option $\left(2.5 \mathrm{~kg} \mathrm{SO}_{2}\right.$ Equiv. $\left./ 1,000 \mathrm{~m}^{3}\right)$, largely due to $\mathrm{SO}_{2}$ emissions from sulphuric acid production (68\%). The next worst option is GAC, with $1.5 \mathrm{~kg} \mathrm{SO}_{2}$ Equiv./1,000 $\mathrm{m}^{3}$, of which $83 \%$ is from $\mathrm{SO}_{2}$ emissions from aluminium sulphate production and hard coal burning, used for the production of GAC. NF is the best option at $0.86 \mathrm{~kg} \mathrm{SO}_{2}$ Equiv./1,000 $\mathrm{m}^{3}$, followed closely by ozonation at $0.92 \mathrm{~kg} \mathrm{SO}_{2}$ Equiv./1,000 $\mathrm{m}^{3}$ (Figure 5).

\subsubsection{Ionizing radiation potential}

As can be seen in Figure 5, GAC has the lowest ionizing radiation potential (27 $\mathrm{kg}$ U235 Equiv. $/ 1,000 \mathrm{~m}^{3}$ ). This is almost seven times lower than for ozonation (203 kg U235 Equiv./1,000 $\mathrm{m}^{3}$ ) which represents the worst option for this impact. SPF is the second best option, followed by NF. For all the options, the source of ionizing radiation is nuclear power present in the electricity mix used for the operation of the plant. Given that ozonation is the greatest consumer of electricity among the four options, it is not surprising that it has the highest impact for this category.

\subsubsection{Ecotoxicity potential - freshwater, marine and terrestrial}

All three types of ecotoxicity exhibit a similar trend, with NF being the best option and SPF and ozonation the worst (Figure 5). For example, freshwater and marine ecotoxicity potentials of SPF are six times higher than those of NF, largely because of emissions to water of copper, nickel and zinc associated with the production of hydrogen peroxide and sodium hydroxide.

For freshwater and marine ecotoxicity, the main contributor to the impacts is the operation of the plants (Figure 6). However, terrestrial ecotoxicity is largely caused by transport, particularly for GAC and SPF to which it contributes $70 \%-75 \%$. For ozonation, the operation of the plant is the main hotspot (85\%); transport adds a further $8 \%$ to the total impact.

\subsubsection{Human toxicity potential}

Ozonation has the highest estimated human toxicity potential, equal to $169 \mathrm{~kg}$ 1,4-dichlorobenzene (DB) Equiv./1,000 $\mathrm{m}^{3}, 60 \%$ of which is from emissions of manganese to freshwaters. The next highest impact is from SPF with $167 \mathrm{~kg}$ 1,4-DB-Equiv., with $51 \%$ attributed to the production of sodium hydroxide, again mostly due to manganese emissions. NF is the best treatment alternative for this impact, with a value of $64 \mathrm{~kg}$ 1,4-DB-Equiv./1,000 $\mathrm{m}^{3}$, followed by GAC at $96 \mathrm{~kg} 1,4-\mathrm{DB}-$ Equiv.

\subsubsection{Land transformation potential - natural, urban and agricultural}

Ozonation has the greatest transformation potential for natural and agricultural land, requiring around $0.1 \mathrm{~m}^{2} \mathrm{yr}$ of natural and $38 \mathrm{~m}^{2} \mathrm{yr}$ of agricultural land per $1,000 \mathrm{~m}^{3}$ of wastewater treated. By contrast, GAC uses 0.04 and $5.6 \mathrm{~m}^{2} \mathrm{yr}$, respectively. NF is the best option for urban land and GAC the worst. Much of the land transformation for all options is associated with the operational requirements. For example, for ozonation this is due to forest transformation, industrial areas and landfill sites associated with electricity generation.

\subsubsection{Particulate matter formation potential}

For this category, NF and GAC are the best alternatives, with a similar impact of $\sim 0.4 \mathrm{~kg}$ PM10 Equiv. $/ 1,000 \mathrm{~m}^{3}$. SPF and ozonation have around a $1 / 3^{\text {rd }}$ higher impact ( $\sim 0.6 \mathrm{~kg}$ PM10 Equiv./1,000 $\mathrm{m}^{3}$ ). For SPF, the impact is mainly from the productions of sulphuric acid $(57 \%)$ and sodium hydroxide (19\%) due to the emission of $\mathrm{SO}_{2}$ which contributes to the formation of particulates. For ozonation, emissions to air of $\mathrm{NO}_{\mathrm{x}}$ and $\mathrm{SO}_{2}$ from electricity generation account for $77 \%$ of the total potential. 
Table 3 - Inventory data for the advanced effluent treatment plants (per 1,000 $\mathrm{m}^{3}$ of wastewater)

\begin{tabular}{|c|c|c|c|c|c|}
\hline Ecoinvent data & $\begin{array}{c}\text { Granular } \\
\text { activated carbon }\end{array}$ & Nanofiltration & $\begin{array}{c}\text { Solar } \\
\text { photo-Fenton }\end{array}$ & Ozonation & 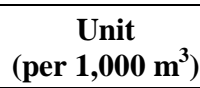 \\
\hline \multicolumn{6}{|c|}{$\begin{array}{l}\text { Construction and parts replacement } \\
\end{array}$} \\
\hline Steel, low-alloyed & 0.0523 & 0.0063 & & & $\mathrm{~kg}$ \\
\hline Reinforcing steel & 0.4150 & 0.0901 & 1.3947 & & $\mathrm{~kg}$ \\
\hline Glass fibre & 0.0175 & 0.0188 & & & $\mathrm{~kg}$ \\
\hline Concrete $^{\mathrm{b}}$ & 0.0008 & 0.0002 & & & $\mathrm{~m}^{3}$ \\
\hline Polyvinyl chloride & & 0.1200 & & & $\mathrm{~kg}$ \\
\hline Chromium steel 18/8 & & & 0.3529 & & $\mathrm{~kg}$ \\
\hline Aluminium, production mix & & & 0.4369 & & $\mathrm{~kg}$ \\
\hline Section bar extrusion, aluminium & & & 0.4369 & & $\mathrm{~kg}$ \\
\hline Anodising, aluminium sheet & & & 0.2521 & & $\mathrm{~m}^{2}$ \\
\hline \multirow[t]{3}{*}{ Glass tube, borosilicate } & & & 0.3025 & & $\mathrm{~kg}$ \\
\hline & & Operation & & & \\
\hline & $\begin{array}{c}\text { Activated carbon } \\
\text { production } \\
\text { (min/mean/max) }\end{array}$ & $\begin{array}{c}\text { Membrane } \\
\text { filtration } \\
\text { (min/mean/max) }\end{array}$ & $\begin{array}{c}\text { Catalyst } \\
(\min / \operatorname{mean} / \max )\end{array}$ & $\begin{array}{c}\text { Ozone } \\
\text { generation } \\
(\mathrm{min} / \mathrm{mean} / \mathrm{max})\end{array}$ & \\
\hline Hard coal supply mix & $15 / 33 / 66$ & & & & $\mathrm{~kg}$ \\
\hline Hard coal, burned at industrial furnace 1-10 MW & $304 / 669 / 1338$ & & & & MJ \\
\hline Natural gas, burned in industrial furnace $>100 \mathrm{~kW}$ & $66 / 145 / 290$ & & & & MJ \\
\hline Water, deionized, at plant & $60 / 132 / 264$ & & & & $\mathrm{~kg}$ \\
\hline Electricity, medium voltage, at grid (Germany) & $8.0 / 17.6 / 35.2$ & & & & $\mathrm{kWh}$ \\
\hline Electricity, medium voltage, at grid (UK) & & $270 / 412 / 554$ & & $150 / 750 / 1300$ & $\mathrm{kWh}$ \\
\hline \multirow[t]{2}{*}{ Iron sulphate, at plant } & & & $13.62 / 34.06 / 54.50$ & & $\mathrm{~kg}$ \\
\hline & $\begin{array}{l}\text { Activated carbon regeneration } \\
\qquad(\mathrm{min} / \mathrm{mean} / \mathrm{max})\end{array}$ & $\begin{array}{c}\text { Cleaning } \\
\text { agents } \\
(\mathrm{min} / \mathrm{mean} / \mathrm{max}) \\
\end{array}$ & $\begin{array}{c}\text { Hydrogen } \\
\text { peroxide } \\
(\mathrm{min} / \mathrm{mean} / \mathrm{max}) \\
\end{array}$ & & \\
\hline Hard coal, burned at industrial furnace 1-10 MW & $75 / 165 / 330$ & & & & MJ \\
\hline Natural gas, burned in industrial furnace $>100 \mathrm{~kW}$ & $260 / 572 / 1144$ & & & & MJ \\
\hline Steam, for chemical process & $15 / 33 / 66$ & & & & $\mathrm{~kg}$ \\
\hline Electricity, medium voltage, at grid (UK) & $0.75 / 1.65 / 3.30$ & & & & $\mathrm{kWh}$ \\
\hline EDTA & & $0.164 / 0.250 / 0.336$ & & & $\mathrm{~kg}$ \\
\hline Sodium hydroxide, $50 \% \mathrm{H}_{2} \mathrm{O}$ & & $0.164 / 0.250 / 0.336$ & & & $\mathrm{~kg}$ \\
\hline Hydrogen peroxide, $50 \% \mathrm{H}_{2} \mathrm{O}$ & & & $20 / 110 / 200$ & & $\mathrm{~kg}$ \\
\hline
\end{tabular}


Electricity, medium voltage, at grid (UK)

Sodium hydroxide, $50 \% \mathrm{H}_{2} \mathrm{O}$

\begin{tabular}{|c|c|c|c|c|}
\hline 29.0 & & & & $\mathrm{kWh}$ \\
\hline 60.0 & & 80.0 & 80.0 & $\mathrm{~kg}$ \\
\hline 80.0 & & & & $\mathrm{~kg}$ \\
\hline 0.30 & & & & $\mathrm{~kg}$ \\
\hline 14.0 & 31.0 & & & $\mathrm{~kg}$ \\
\hline 7.00 & 31.0 & & & $\mathrm{~kg}$ \\
\hline \multicolumn{5}{|l|}{1.10} \\
\hline & 36.0 & 130 & & $\mathrm{~kg}$ \\
\hline \multirow[t]{2}{*}{0.60} & 0.60 & & & $\mathrm{~kg}$ \\
\hline & 0.3584 & & & $\mathrm{~kg}$ \\
\hline \multicolumn{5}{|c|}{ Waste management } \\
\hline \multirow[t]{3}{*}{$5 / 11 / 22$} & & & & $\mathrm{~kg}$ \\
\hline & 0.3584 & & & $\mathrm{~kg}$ \\
\hline & & 46.06 & & $\mathrm{~kg}$ \\
\hline \multicolumn{5}{|c|}{ Decommissioning $^{\mathrm{d}}$} \\
\hline 0.0234 & 0.0048 & 0.0697 & & $\mathrm{~kg}$ \\
\hline 0.0175 & 0.0188 & & & $\mathrm{~kg}$ \\
\hline \multirow[t]{4}{*}{0.4500} & 0.0900 & & & $\mathrm{~kg}$ \\
\hline & 0.0204 & & & $\mathrm{~kg}$ \\
\hline & & 0.0437 & & $\mathrm{~kg}$ \\
\hline & & 0.3025 & & $\mathrm{~kg}$ \\
\hline 0.4439 & 0.0914 & 1.3250 & & $\mathrm{~kg}$ \\
\hline \multirow[t]{4}{*}{1.4250} & 0.2850 & & & $\mathrm{~kg}$ \\
\hline & 0.0996 & & & $\mathrm{~kg}$ \\
\hline & & 0.8301 & & $\mathrm{~kg}$ \\
\hline & & 0.3352 & & $\mathrm{~kg}$ \\
\hline \multicolumn{5}{|c|}{ Transport $^{\mathrm{e}}$} \\
\hline $44 / 57 / 81$ & $19.8^{\mathrm{f}}$ & $58 / 80 / 102$ & 16 & t.km \\
\hline
\end{tabular}

Aluminum sulphate, powde

Polymer (acrylonitrile-butadiene-styrene copolymer)

Carbon dioxide, liquid

Calcium hydroxide

Phosphoric acid, industrial grade

Sulphuric acid, liquid

Chlorine, liquid

Spiral wound modules ${ }^{\mathrm{c}}$

Disposal, bitumen, $1.4 \%$ water, to sanitary landfill

Disposal, plastics, $15.3 \%$ water, municipal incineration

Cement, hydrated, $0 \%$ water, to residual material landfill

Disposal steel, $0 \%$ water, to inert material landfill

Disposal, inert waste, $5 \%$ water, to material landfill

Disposal, concrete, $5 \%$ water, to inert material landfill

Disposal, polyethylene, $0.4 \%$ water, to sanitary landfill

Disposal, aluminium, $0 \%$ water, to sanitary landfill

Disposal, glass $0 \%$ water, to inert material landfill

Steel - recycled

Concrete $^{\mathrm{b}}$ - recycling

Polyethylene - recycling

Aluminium - recycling

Chromium steel 18/8 - recycling

$58 / 80 / 102$

${ }^{a}$ Amount of fresh activated carbon (min/mean/max): 5/11/22 kg/1,000 $\mathrm{m}^{3}$; amount of regenerated activated carbon over the lifetime of 60 year (min/mean/max): $25 / 55 / 110$ $\mathrm{kg} / 1,000 \mathrm{~m}^{3}$.

${ }^{\mathrm{b}}$ Concrete density: $2,300 \mathrm{~kg} / \mathrm{m}^{3}$

${ }^{\mathrm{S}} \mathrm{See}$ Table S2 in the SI for details.

${ }^{\mathrm{d}}$ Concrete: $24 \%$ recycled and 76\% landfilled; glass: $100 \%$ landfilled; glass fibre: $100 \%$ landfilled; metals: $95 \%$ recycled and 5\% landfilled; plastics: $83 \%$ recycled and $17 \%$ landfilled.

${ }^{\mathrm{e}}$ All distances were set to $200 \mathrm{~km}$ except for fresh GAC transport to the wastewater treatment site, assumed at 1,000 km (imported from central Germany).

${ }^{\mathrm{f}}$ Negligible variation. 

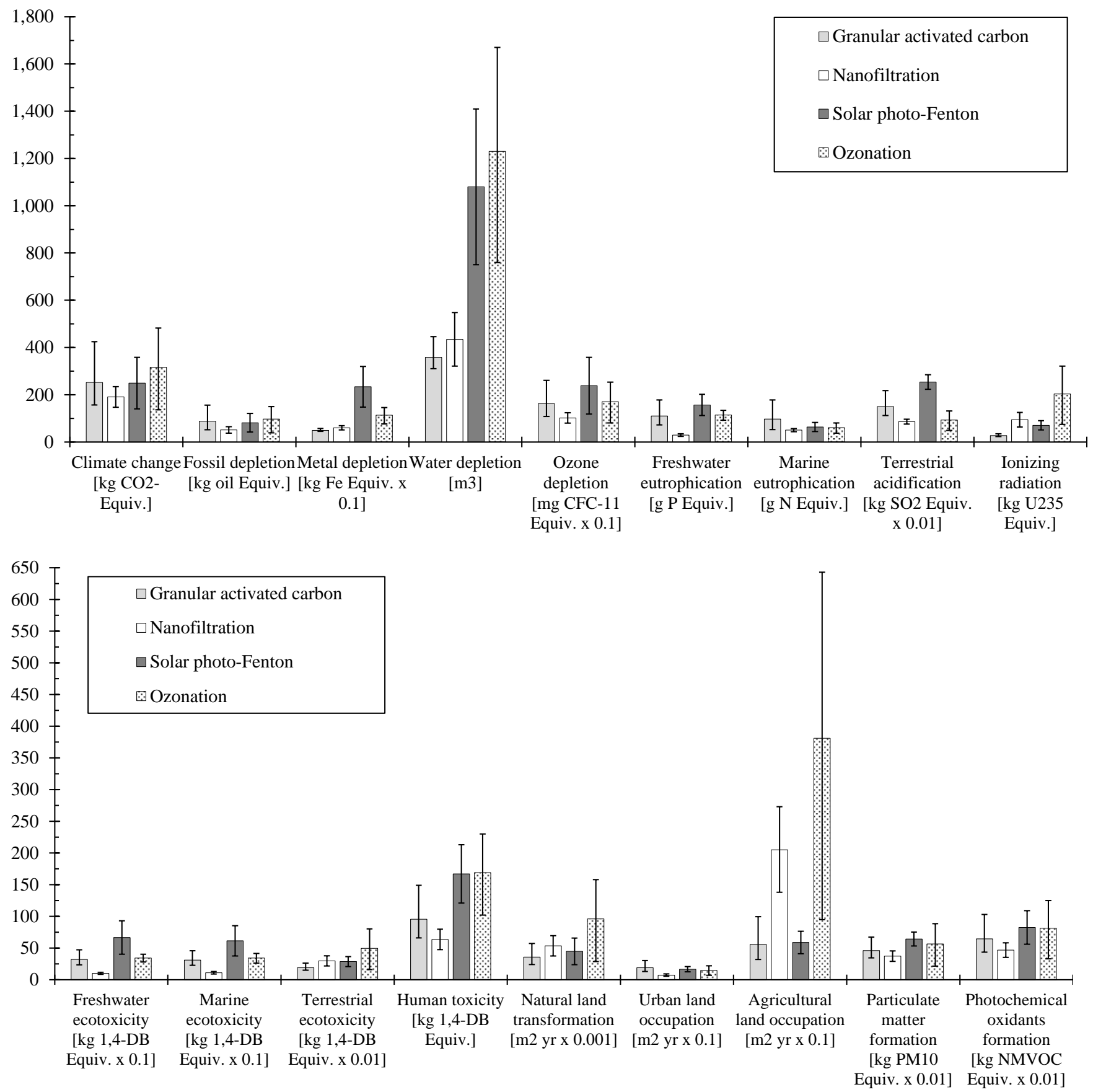

Figure 5 - Life cycle impact of the advanced treatment techniques for PPCP compounds. All impacts are expressed per $1,000 \mathrm{~m}^{3}$ of wastewater. The error bars represent the minimum and maximum values for the parameters as specified in Table 3. DB - dichlorobenzene. NVVOC: non-methane volatile organic compounds) 

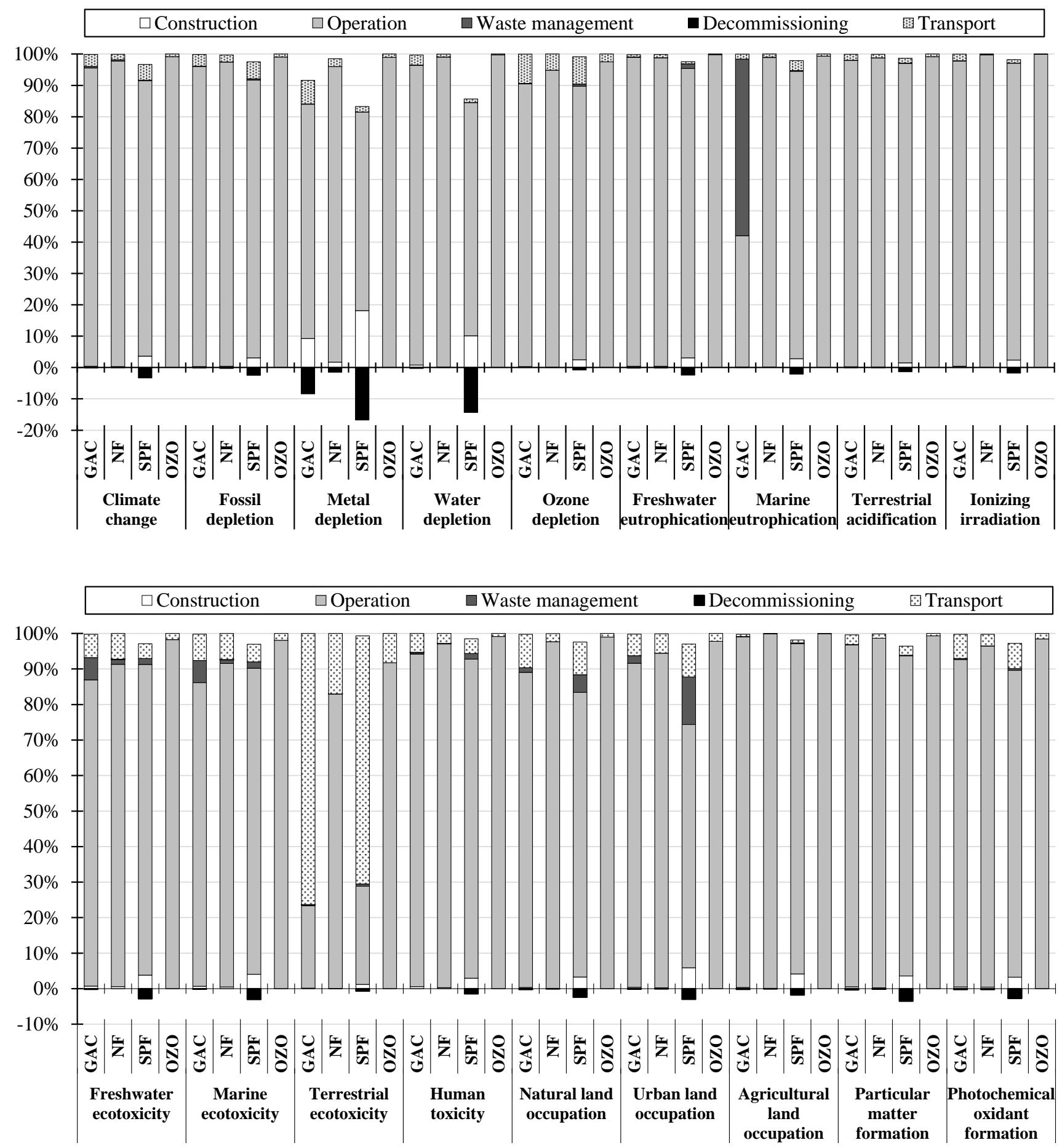

Figure 6 - Contribution of different life cycle stages to the impacts of advanced treatment options (Waste management includes decommissioning)

\subsubsection{Photochemical oxidants formation potential}

At 0.65 and $0.47 \mathrm{~kg}$ non-methane volatile organic compounds (NMVOC) Equiv. $/ 1,000 \mathrm{~m}^{3}, \mathrm{GAC}$ and $\mathrm{NF}$ are the best options for this category. The worst options - SPF and ozonation - have a similar impact ( 0.82 and $0.81 \mathrm{~kg}$ NMVOC Equiv., respectively). The main contributor across all four alternatives is the operation of the plant, related to nitrogen oxide emissions from electricity generation. Transport also contributes around 5\%-10\% to the impact from GAC and SPF. 


\subsubsection{Comparison of results with literature}

The literature on life cycle environmental impacts of advanced wastewater treatment technologies in general is scarce and, as far as we know, there are no studies that considered specifically the impacts of PPCP advanced treatment. The existing studies also differ greatly in terms of study goals, system boundaries, functional units, assumptions and impact assessment methodologies. Therefore, a meaningful comparison among them is difficult if impossible. Nevertheless, an attempt is made to benchmark the findings of the present study with some others. The focus is on climate change, for which the impact assessment methodology is mainly consistent across different LCA studies. The comparison of other impacts is not possible as other studies did not use the ReCiPE methodology applied here.

For example, Jeswani et al. (2015) considered GAC for removal of organic carbon produced from decaying natural occurring matter. Their estimated climate change potential of $155 \mathrm{~kg} \mathrm{CO}_{2}$ Equiv./1,000 $\mathrm{m}^{3}$ agrees well with the lower value in the range obtained here $(157-425 \mathrm{~kg} \mathrm{CO}$ Equiv.). For NF, the only other LCA study found is that by Bonton et al. (2012) which focused on potable rather than wastewater treatment, based in Canada. The reported climate change potential was $40 \mathrm{~kg} \mathrm{CO}_{2}$ Equiv. $/ 1,000 \mathrm{~m}^{3}$, almost a factor of five lower than the mean value in the present work (191 $\mathrm{kg} \mathrm{CO}_{2}$ Equiv.). In addition to the differences in other assumptions, this discrepancy in the results is probably largely due to Canadian electricity which is largely derived from hydropower, as opposed to fossil fuels prevalent in the UK grid. On the other hand, the impact from SPF estimated by Muñoz et al. (2007) was much higher than here: $5,000 \mathrm{~kg}$ vs the mean value of $248 \mathrm{~kg}$ $\mathrm{CO}_{2}$ Equiv./1,000 $\mathrm{m}^{3}$. This is likely due to a much higher amount of hydrogen peroxide and catalysts used during the pilot scale experiments to treat wastewater containing methylphenyl glycine.

\subsection{Parametric analysis}

As mentioned earlier, the results discussed in the previous sections refer to the mean values of the key operating parameters shown in Table 3 for the respective treatment options. To examine the influence of these parameters, a parametric analysis was carried out assuming in turn the minimum and maximum values of the parameters in Table 3. The resulting variations in the impacts are shown as error bars in Figure 5. As can be seen, most impacts from SPF and ozonation are susceptible to the variations in the key operating parameters and vary widely. Due to this, for some of the categories they become comparable to the other two alternatives. These include climate change, ozone depletion, ecotoxicity and photochemical oxidants, where the minimum values for SPF and ozonation are similar or lower than the respective mean values for GAC. On the other hand, NF showed to be the least sensitive to the variation in the operating parameters.

\subsection{Freshwater ecotoxicity potential of PPCP compounds}

This section considers freshwater ecotoxicity potential of the target PPCPs when released with the effluent to freshwaters or to agricultural land, the latter if the effluent is used for irrigation. Both the effluents treated by the advanced methods and those not subjected to such treatment but discharged directly after the secondary treatment are considered. The aim is to find out if and by how much the advanced treatment could contribute to reducing the overall ecotoxicity potential of the target PPCPs compared to the effluent from the conventional WWTPs. The USEtox methodology was used for these purposes (Henderson et al. 2011). Note that the freshwater potential of the advanced treatment options discussed in section 3.1.8 were estimated using the ReCiPe methodology so that the estimates presented in this section are not comparable. Note also that it was not possible to use the ReCiPe methodology to estimate the ecotoxicity potential of the target PPCP compounds due to a lack of their characterisation factors. 
The USEtox characterisation factors for freshwater ecotoxicity potential of the target PPCPs are given in Table 4, distinguishing between their potential impact when released to freshwaters and agricultural land. It can be noticed that the latter is much lower than the former for each PPCP.

Table 4 - USEtox characterization factors for freshwater ecotoxicity of target PPCP compounds (Henderson et al. 2011).

\begin{tabular}{lcc}
\hline \multirow{2}{*}{ Compound } & \multicolumn{2}{c}{ Characterisation factor $\left(\mathrm{CTU}_{\mathrm{e}} / \mathrm{kg}\right)^{\mathrm{a}}$} \\
\cline { 2 - 3 } & $\begin{array}{c}\text { Emission to } \\
\text { freshwater }^{\mathrm{b}}\end{array}$ & $\begin{array}{c}\text { Emission to } \\
\text { agricultural land (irrigation })^{\mathrm{b}}\end{array}$ \\
\hline Diclofenac & 2,670 & 105 \\
Ibuprofen & 209 & 4 \\
Trimethoprim & 474 & 19 \\
Erythromycin & 24,900 & 3,120 \\
Sulfamethoxazole & 2,990 & 195 \\
Carbamazepine & 854 & 13 \\
Estrone & 21,400 & 19 \\
$17 \beta$-estradiol & $184,000,000$ & 255,000 \\
Triclosan & 106,000 & 200 \\
\hline${ }^{\mathrm{a}} \mathrm{CTU}_{\mathrm{e}}:$ comparative toxic units. It represents an estimate of the potentially affected fraction of species $(\mathrm{PAF})$ over time and \\
volume per mass of a compound emitted to the environment. CTU $\mathrm{C}_{\mathrm{e}} / \mathrm{kg}=\left(\mathrm{PAF} \mathrm{m}^{3} \cdot \mathrm{day}\right) / \mathrm{kg}($ Henderson et al. 2011). \\
${ }^{\mathrm{b}} \mathrm{CTU}_{\mathrm{e}}$ values from Alfonsín et al. (2014).
\end{tabular}

The results are summarised in Figure 7 and detailed in Tables S3-S6 in the SI. As indicated in Figure $7 \mathrm{a}$, releasing the PPCPs in the effluent to freshwaters without advanced treatment has the mean ecotoxicity potential of $1700.8 \mathrm{CTU}_{\mathrm{e}} / 1,000 \mathrm{~m}^{3}$ (97\% of which is due to $17 \beta$-estradiol; see Table S3). By comparison, this is equivalent to the total life cycle freshwater ecotoxicity of GAC treatment at the maximum operating conditions $\left(1,710 \mathrm{CTU}_{\mathrm{e}} / 1,000 \mathrm{~m}^{3}\right.$; Table S4). Figure $7 \mathrm{a}$ also shows that at the mean operating conditions GAC must achieve the removal efficiency above $65 \%$ and ozonation must remove at least $75 \%$ of the PPCPs to have the ecotoxicity potential comparable to that of the secondary effluent not treated by an advanced method. SPF can have a lower ecotoxicity than the effluents without advanced treatment only if operating at the minimum operating requirements and removing PPCPs with an efficiency of over $85 \%$. The only treatment option capable of reducing the ecotoxicity below that of the secondary effluent without the advanced treatment across the range of operating conditions is $\mathrm{NF}$, with $1,157.3 \mathrm{CTU}_{\mathrm{e}} / 1,000 \mathrm{~m}^{3}$ for the maximum operating requirements, mean PPCP concentrations and the lowest removal efficiency (65\%). This is $30 \%$ lower than the minimum ecotoxicity of the effluent without advanced treatment $\left(1500.7 \mathrm{CTU}_{\mathrm{e}} / 1,000 \mathrm{~m}^{3}\right)$.

On the other hand, releasing the effluent without advanced treatment to agricultural land achieves a much higher reduction of freshwater ecotoxicity than treating it by any of the advanced treatments. In that case, the mean ecotoxicity potential is equivalent to $4.8 \mathrm{CTU}_{\mathrm{e}} / 1,000 \mathrm{~m}^{3}$ (see Figure $7 \mathrm{~b}$ and Table S5 in the SI). This is 354 times lower than the impact of the secondary effluent released to freshwaters for the mean concentrations of PPCPs and 3.5 times lower than the impact when $99 \%$ of PPCPs are removed and released to freshwaters (for the latter, see Table S4). The difference between treating and not treating the effluent by an advanced method is even starker when considering its release to land, where the life cycle ecotoxicity of all the treatment options outweighs the impact of the effluent without advanced treatment by several orders of magnitude. For example, NF, the best option in this case, has at least 80 times higher ecotoxicity potential for a $99 \%$ removal efficiency (386 $\mathrm{CTU}_{\mathrm{e}} / 1,000 \mathrm{~m}^{3}$; Table $\mathrm{S} 6$ ) than the effluent without advanced treatment released to agricultural land.

Therefore, on the basis of these findings, and also taking into account that the advanced treatment generates many additional impacts as discussed in the previous sections, it could be argued that PPCPs should not be subjected to advanced treatment. Instead, the secondary effluent should be utilised for irrigation of agricultural land rather than released to freshwaters to reduce the overall 
ecotoxicity. However, if the effluent is released to freshwaters, then nanofiltration should be used as it is the only alternative capable of reducing the ecotoxicity below the impact of the secondary effluent without advanced treatment.

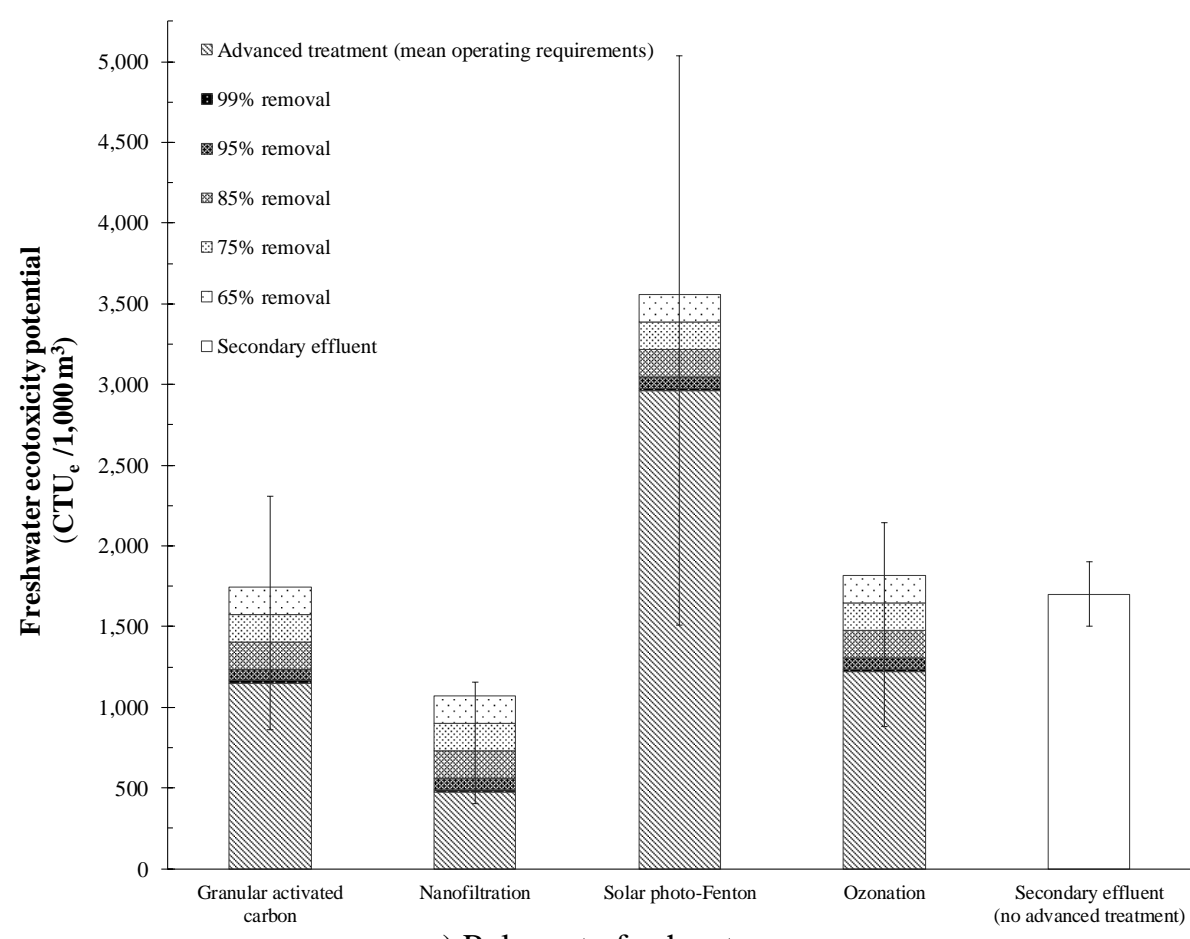

a) Release to freshwaters

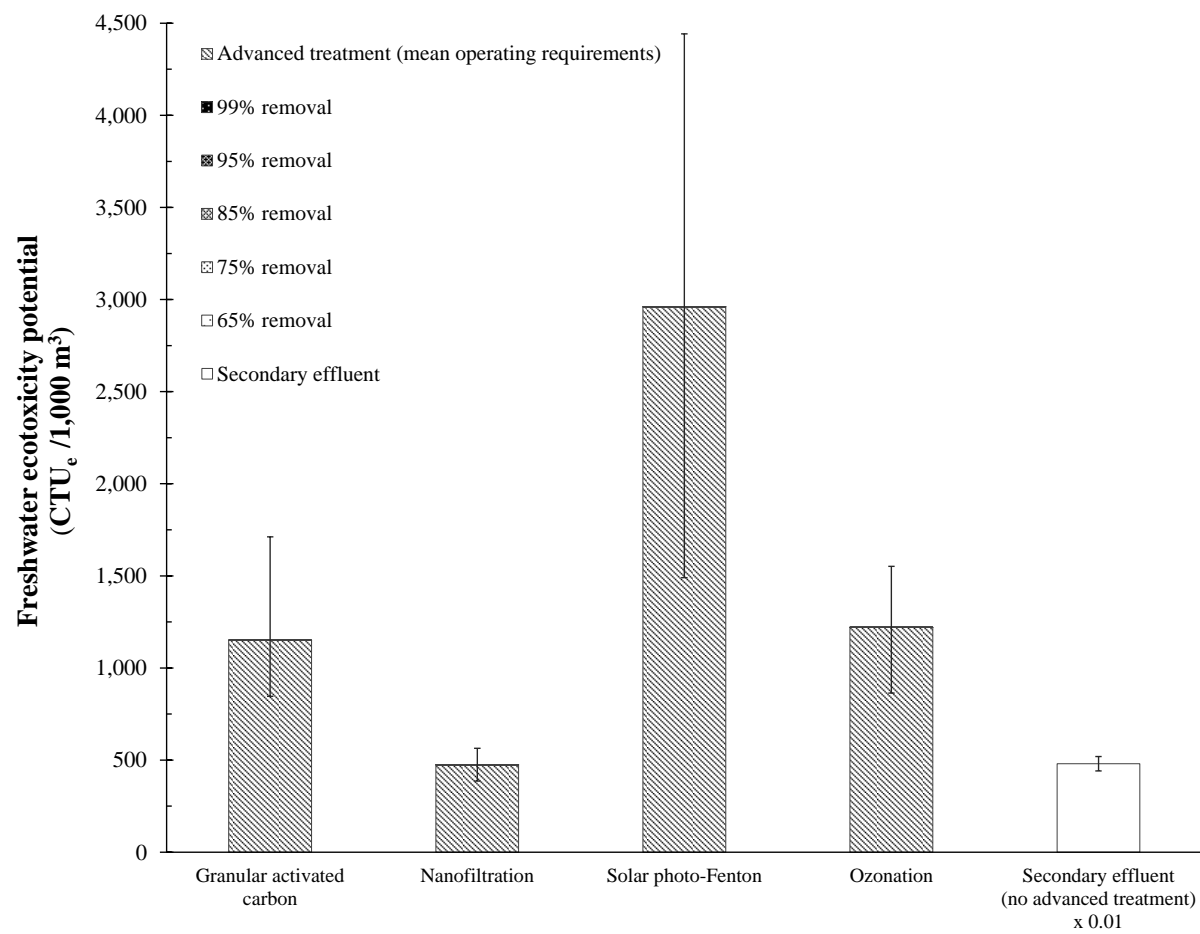

b) Release to agricultural land

Figure 7 - Freshwater ecotoxicity potential of effluent from advanced treatment plants compared to the impact from the secondary effluent without advanced treatment for different PPCP removal efficiencies (The impact estimated using the USEtox methodology. "Advanced treatment" refers to the life cycle of the treatment process. The impact for "secondary effluent without advanced treatment" in figure b) has been multiplied by 100 as it was too small to show on the graph). 


\subsection{Wastewater reuse}

Agricultural irrigation is at present the most common option for reuse of wastewater in Europe. It is particularly practiced in water-stressed regions. Its use is favoured also because of lower effluent quality requirements compared to potable water, which can be achieved by conventional secondary or simple tertiary treatments (Bdour et al. 2009, Bixio et al. 2006). Furthermore, given that agriculture is one of the largest water consumers, reusing wastewater provides a reliable and cheaper source of freshwater, reduces water stress and the need for other water sources (Barceló \& Petrović 2011, Melin et al. 2006).

As demonstrated in this work, the PPCPs in the effluent discharged after conventional treatment and those subjected to the advanced treatment have low freshwater ecotoxicity potential when applied to agricultural land, although some compounds, such as diclofenac and carbamazepine, show evidence of soil accumulation (Ternes et al. 2007, Xu et al. 2009, Yu et al. 2013). Still, their removal from wastewaters would potentially create a greater ecotoxicity potential as well as a number of other impacts, such as climate change, acidification, eutrophication, human toxicity, etc.

The results of this work also suggest that the removal of PPCPs to achieve the water quality similar to potable water for release to freshwaters is not environmentally sustainable since it creates a similar or greater freshwater ecotoxicity impact than the effluent without advanced treatment. However, if the treatment is aimed at reuse of treated water for drinking, then advanced effluent treatment is environmentally more sustainable than some drinking-water treatment methods, particularly desalination (Muñoz \& Fernández-Alba 2008, Pasqualino et al. 2011, Sala \& Serra 2004, Shannon et al. 2008). However, many obstacles need to be overcome to enable direct potable reuse of wastewater from advanced treatment methods, such as pumping and buffering requirements (blending ratios with drinking water, reservoir maintenance), economic viability, generation of harmful by-products, regulations and social acceptance (Lim et al. 2008, NRC 2012, Salgot et al. 2006, Urkiaga et al. 2006).

While advanced treatment of PPCPs may not be warranted, site-control and monitoring of compounds originating from WWTPs effluents and in freshwaters are required to avoid contamination of water sources and consequently drinking water supplies. This is particularly important as water in many cities are found to contain these substances (Benotti et al. 2009, Gaffney et al. 2015, Webb et al. 2003). However, the risks posed to humans by these chemicals in potable water supplies remain unknown (Gaffney et al. 2015, Gibs et al. 2007, Huerta-Fontela et al. 2011, Jones et al. 2005, Kleywegt et al. 2011).

\section{Conclusions}

This paper considered life cycle environmental impacts of four advanced treatment techniques for nine target PPCP compounds. The results suggest that, on average, NF has the lowest impacts for 13 out of 18 categories. GAC is the best alternative for five impacts, including metal and water depletion, but it has the highest marine eutrophication of all the options. SPF and ozonation are the least sustainable for eight impacts, including, acidification and ecotoxicity for the former and climate change and ionizing radiation for the latter. However, most impacts from SPF and ozonation vary widely with the operating parameters and, when considering their ranges rather than the mean values, for some impacts they become comparable to the other two alternatives. These include climate change, ozone depletion, ecotoxicity and photochemical oxidants, where the minimum values for ozonation are lower than the respective mean values for GAC.

On the other hand, GAC and NF are favoured since they have greater removal efficiencies for heavy metals and also avoid production of harmful by-products during the treatment, thus being more suitable for potable reuse of wastewater. Moreover, their life cycle freshwater ecotoxicity is lower 
than for effluents released from conventional WWTPs to freshwaters without the advanced treatment of PPCPs. GAC, SPF and ozonation should not be used on the grounds of reducing freshwater ecotoxicity.

Overall, releasing the effluent without advanced treatment to agricultural land achieves a much higher reduction of freshwater ecotoxicity than treating it by any of the advanced treatments and releasing to freshwaters. This is due to the freshwater ecotoxicity potential generated by the treatments themselves being higher than the ecotoxicity potential of the PPCPs being treated. Therefore, the use of advanced effluent treatment for agricultural purposes is not recommended and only NF and possibly GAC should be used if the primary aim is reuse of treated wastewater as potable water.

\section{Nomenclature}

$\begin{array}{ll}\mathrm{C}_{1} & \text { material requirements for a smaller-scale plant }\left(\mathrm{kg} / \mathrm{m}^{3}\right) \\ \mathrm{C}_{2} & \text { material requirements for a larger-scale plant }\left(\mathrm{kg} / \mathrm{m}^{3}\right) \\ \mathrm{c}_{1} & \text { treatment capacity of a smaller-scale plant }\left(\mathrm{m}^{3}\right) \\ \mathrm{c}_{2} & \text { treatment capacity of a larger-scale plant }\left(\mathrm{m}^{3}\right) \\ \mathrm{D}_{\text {ozone }} & \text { applied ozone dosage }\left(\mathrm{kg} \text { ozone } / \mathrm{m}^{3}\right) \\ \mathrm{EBCT} & \text { empty-bed contact time }(\mathrm{min}) \\ \mathrm{E}_{\text {ozonation }} & \text { electricity consumption for ozonation }(\mathrm{kWh}) \\ \mathrm{E}_{\text {ozone }} & \text { electricity consumption for ozone generation }\left(\mathrm{kWh} / \mathrm{kg}_{\text {ozone }}\right) \\ \mathrm{F}_{\mathrm{GAC}} & \text { amount of fresh GAC needed for the treatment }(\mathrm{kg}) \\ \mathrm{m}_{\mathrm{GAC}} & \text { amount of granular activated carbon in the bed }(\mathrm{kg}) \\ \mathrm{m}_{\text {loss }} & \text { percentage of GAC lost during regeneration }(\%) \\ \mathrm{N}_{\mathrm{BR}} & \text { total number of bed replacements over the lifespan of } 60 \text { years }(-) \\ \mathrm{n}_{\text {max }} & \text { maximum number of bed regenerations before replacement }(10) \\ \mathrm{n}_{\mathrm{r}} & \text { number of bed regenerations after the previous bed replacement (-) } \\ \mathrm{Q}_{\text {inf }} & \text { influent flow to be treated }\left(\mathrm{m}^{3} / \mathrm{min}\right) . \\ \mathrm{R}_{\mathrm{GAC}} & \text { amount of regenerated GAC }(\mathrm{kg}) \\ \mathrm{t}_{\mathrm{GAC}} & \text { bed service time (days) } \\ \mathrm{T}_{\text {treatment }} & \text { treatment time (days) } \\ \mathrm{V}_{\mathrm{GAC}} & \text { volume of granular activated carbon in the bed }\left(\mathrm{m}^{3}\right) \\ \mathrm{V}_{\text {inf }} & \text { influent volume to be treated, i.e. the functional unit }\left(\mathrm{m}^{3}\right) .\end{array}$

\section{Acknowledgments}

The authors would like to acknowledge CNPq (Brazilian National Council for Scientific and Technological Development) for financial support (grant number 238021/2012-2).

\section{References}

Al-Amoudi A, Lovitt RW. 2007. Fouling strategies and the cleaning system of NF membranes and factors affecting cleaning efficiency. J. Memb. Sci. 303(1-2):4-28

Alfonsín C, Hospido A, Omil F, Moreira MT, Feijoo G. 2014. PPCPs in wastewater - Update and calculation of characterization factors for their inclusion in LCA studies. J. Clean. Prod. 1-11

Alturki AA, Tadkaew N, McDonald J a., Khan SJ, Price WE, Nghiem LD. 2010. Combining MBR and NF/RO membrane filtration for the removal of trace organics in indirect potable water reuse applications. J. Memb. Sci. 365(1-2):206-15

Barceló D, Petrović M. 2011. Waste Water Treatment and Reuse in the Mediterranean Region. Berlin, Germany: Springer

Bayer P, Heuer E, Karl U, Finkel M. 2005. Economical and ecological comparison of granular activated carbon (GAC) adsorber refill strategies. Water Res. 39(9):1719-28

Bdour AN, Hamdi MR, Tarawneh Z. 2009. Perspectives on sustainable wastewater treatment technologies and reuse options in the urban areas of the Mediterranean region. Desalination. 237(1-3):162-74

BEIS. 2016. Energy trends - Electricity. London, UK 
Bellona C, Drewes JE, Xu P, Amy G. 2004. Factors affecting the rejection of organic solutes during NF/RO treatment A literature review. Water Res. 38(12):2795-2809

Benotti MJ, Trenholm R a, Vanderford BJ, Holady JC, Stanford BD, Snyder S a. 2009. Pharmaceuticals and endocrine disrupting compounds in U.S. drinking water. Environ. Sci. Technol. 43(3):597-603

Bixio D, Thoeye C, De Koning J, Joksimovic D, Savic D, et al. 2006. Wastewater reuse in Europe. Desalination. 187(13):89-101

Bixio D, Thoeye C, Wintgens T, Ravazzini a., Miska V, et al. 2008. Water reclamation and reuse: implementation and management issues. Desalination. 218(1-3):13-23

Blasco J, Delvalls A. 2008. Impact of emergent contaminants in the environment: Environmental risk assessment. In Handbook of Environmental Chemistry, Vol. 5, eds. D Barceló, AG Kostianoy, pp. 169-88. Springer-Verlag. Berlin, DE ed.

Bolong N, Ismail a. F, Salim MR, Matsuura T. 2009. A review of the effects of emerging contaminants in wastewater and options for their removal. Desalination. 238(1-3):229-46

Bonton A, Bouchard C, Barbeau B, Jedrzejak S. 2012. Comparative life cycle assessment of water treatment plants. Desalination. 284:42-54

Boxall AB a. 2004. The environmental side effects of medication. EMBO Rep. 5(12):1110-16

BRE / DEFRA. 2010. Construction resources and waste roadmap. Watford

Bruggen B Van der, Mänttäri M, Nyström M. 2008. Drawbacks of applying nanofiltration and how to avoid them: A review. Sep. Purif. Technol. 63(2):251-63

Bui XT, Vo TPT, Ngo HH, Guo WS, Nguyen TT. 2016. Multicriteria assessment of advanced treatment technologies for micropollutants removal at large-scale applications. Sci. Total Environ. 563-564:1050-67

Burns N, Hunter G, Jackman A, Hulsey B, Coughenour J, Walz T. 2007. The Return of Ozone and the Hydroxyl Radical to Wastewater Disinfection. Ozone Sci. Eng. 29(4):303-6

Carlsson C, Johansson AK, Alvan G, Bergman K, Kühler T. 2006. Are pharmaceuticals potent environmental pollutants?. Part I: Environmental risk assessments of selected active pharmaceutical ingredients. Sci. Total Environ. 364(1-3):67-87

Carmona E, Andreu V, Picó Y. 2014. Occurrence of acidic pharmaceuticals and personal care products in Turia River Basin: From waste to drinking water. Sci. Total Environ. 484(1):53-63

Cases V, Alonso V, Argandoña V, Rodriguez M, Prats D. 2011. Endocrine disrupting compounds: A comparison of removal between conventional activated sludge and membrane bioreactors. Desalination. 272(1-3):240-45

CDPH. 2009. Regulations Related to Recycled Water

Celle-Jeanton H, Schemberg D, Mohammed N, Huneau F, Bertrand G, et al. 2014. Evaluation of pharmaceuticals in surface water: Reliability of PECs compared to MECs. Environ. Int. 73:10-21

Clements M. 2002. Granular activated carbon management at a water treatment plant. Rand Afrikaans University

Cleuvers M. 2004. Mixture toxicity of the anti-inflammatory drugs diclofenac, ibuprofen, naproxen, and acetylsalicylic acid. Ecotoxicol. Environ. Saf. 59(3):309-15

Coulson J, Richardson J, Sinnontt RK. 1993. Chemical Engineering. Oxford: Butterworth-Heinemann Ltd. 2nd Revise ed.

Creek D, Davidson J. 2000. Granular Activated Carbon. In Treatment Technologies for Removal of Methyl Tertiary Butyl Ether (MTBE) from Drinking Water, ed. G Melin, pp. 211-58. Fountain Valley, California, U.S.A.: National Water Research Institute. 2nd ed.

Creek D, Davidson J, Alpine Environmental Inc. 2001. Treating MTBE-Impacted Drinking Water Using Granular Activated Carbon. Fountain Valley, California, U.S.A.

Cyna B, Chagneaub G, Bablon G, Tanghe N. 2002. Two years of nanofiltration at the M \& y-sur-Oise plant, France. . 147:69-75

Dalahmeh S, Baresel C. 2014. Reclaimed Wastewater Use Alternatives and Quality Standards From Global to Country Perspective : Spain versus Abu Dhabi Emirate Sahar Dalahmeh. Stockholm

Daughton CG. 2001. Emerging pollutants, and communicating the science of environmental chemistry and mass spectrometry: Pharmaceuticals in the environment. J. Am. Soc. Mass Spectrom. 12(10):1067-76

Daughton CG. 2004. PPCPs in the Environment : Future Research - Beginning with the End Always in Mind. In Pharmaceuticals in the Environment, ed. K Kummerer, pp. 463-95. New York, USA: Springer. 2nd ed.

DEFRA. 2012. Waste water treatment in the United Kingdom. London

Delgado LF, Charles P, Glucina K, Morlay C. 2012. The removal of endocrine disrupting compounds, pharmaceutically activated compounds and cyanobacterial toxins during drinking water preparation using activated carbon-A review. Sci. Total Environ. 435-436:509-25

Eggen RIL, Hollender J, Joss A, Scha M. 2014. Reducing the Discharge of Micropollutants in the Aquatic Environment: The Bene fi ts of Upgrading Wastewater Treatment Plants. Environ. Sci. Technol. 48:7683-89

EPA. 2012. Guidelines for Water Reuse

European commission. 2015. Commission implementing decision 2015/495. Dir. 2008/105/EC

Farré M La, Pérez S, Kantiani L, Barceló D. 2008. Fate and toxicity of emerging pollutants, their metabolites and 
transformation products in the aquatic environment. TrAC - Trends Anal. Chem. 27(11):991-1007

Fedorenkova A, Vonk JA, Lenders HJR, Ouborg NJ, Breure AM, Hendriks a. J. 2010. Ecotoxicogenomics: Bridging the gap between genes and populations. Environ. Sci. Technol. 44(11):4328-33

Fent K, Weston A a., Caminada D. 2006. Ecotoxicology of human pharmaceuticals. Aquat. Toxicol. 76(2):122-59

Fick J, Soderstrom H, Lindberg RH, Phan C, Tysklind M, Larsson JDG. 2009. Contamination of Surface, Ground, and Drinking Water From Pharmaceutical Production. Environ. Toxicol. Chem. 28(12):2522-27

Frischknecht R, Jungbluth N, Althaus H-J, Doka G, Dones R, et al. 2004. The ecoinvent Database: Overview and Methodological Framework (7 pp). Int. J. Life Cycle Assess. 10(1):3-9

Fu F, Wang Q. 2011. Removal of heavy metal ions from wastewaters: A review. J. Environ. Manage. 92(3):407-18

Gaffney V de J, Almeida CMM, Rodrigues A, Ferreira E, Benoliel MJ, Cardoso VV. 2015. Occurrence of pharmaceuticals in a water supply system and related human health risk assessment. Water Res. 72:199-208

Gibs J, Stackelberg PE, Furlong ET, Meyer M, Zaugg SD, Lippincott RL. 2007. Persistence of pharmaceuticals and other organic compounds in chlorinated drinking water as a function of time. Sci. Total Environ. 373(1):240-49

Goedkoop M, Heijungs R, Huijbregts M, Schryver A De, Struijs J, Zelm R Van. 2009. ReCiPe 2008. Amersfoort, Netherlands

Goel J, Kadirvelu K, Rajagopal C, Garg VK. 2005. Removal of lead(II) by adsorption using treated granular activated carbon: Batch and column studies. J. Hazard. Mater. 125(1-3):211-20

Gogate PR, Pandit AB. 2004a. A review of imperative technologies for wastewater treatment I: Oxidation technologies at ambient conditions. Adv. Environ. Res. 8(3-4):501-51

Gogate PR, Pandit AB. 2004b. A review of imperative technologies for wastewater treatment II: Hybrid methods. Adv Environ. Res. 8(3-4):553-97

Hanjra MA, Blackwell J, Carr G, Zhang F, Jackson TM. 2012. Wastewater irrigation and environmental health: Implications for water governance and public policy. Int. J. Hyg. Environ. Health. 215(3):255-69

Heberer T. 2002. Tracking persistent pharmaceutical residues from municipal sewage to drinking water. J. Hydrol. 266(3-4):175-89

Henderson AD, Hauschild MZ, Van De Meent D, Huijbregts M a J, Larsen HF, et al. 2011. USEtox fate and ecotoxicity factors for comparative assessment of toxic emissions in life cycle analysis: Sensitivity to key chemical properties. Int. J. Life Cycle Assess. 16(8):701-9

Hill R, Chu M. 2009. The Pharmerging Future. Pharm. Exec. 29(7):44-52

Huerta-Fontela M, Galceran MT, Ventura F. 2011. Occurrence and removal of pharmaceuticals and hormones through drinking water treatment. Water Res. 45(3):1432-42

Hughes SR, Kay P, Brown LE. 2013. Global synthesis and critical evaluation of pharmaceutical data sets collected from river systems. Environ. Sci. Technol. 47(2):661-77

ISO. 2006. Environmental management — Life cycle assessment — Principles and framework

Jeswani HK, Gujba H, Brown NW, Roberts EPL, Azapagic A. 2015. Removal of organic compounds from water: life cycle environmental impacts and economic costs of the Arvia process compared to granulated activated carbon. $J$. Clean. Prod. 89:203-13

Jones-Lepp TL, Stevens R. 2007. Pharmaceuticals and personal care products in biosolids/sewage sludge: The interface between analytical chemistry and regulation. Anal. Bioanal. Chem. 387(4):1173-83

Jones O a., Lester JN, Voulvoulis N. 2005. Pharmaceuticals: A threat to drinking water? Trends Biotechnol. 23(4):16367

Kärrman E. 2001. Strategies towards sustainable wastewater management. Urban Water. 3(1-2):63-72

Khetan SK, Collins TJ. 2007. Human pharmaceuticals in the aquatic environment a review. Chem. Rev. 107:2319-64

Kim I, Tanaka H. 2011. Energy consumption for PPCPs removal by O3 and O3/UV. Ozone Sci. Eng. 33(2):150-57

Klamerth N. 2011. Application of a solar photo-Fenton for the treatment of contaminants in municipal wastewater effluents. University of Almeria

Kleywegt S, Pileggi V, Yang P, Hao C, Zhao X, et al. 2011. Pharmaceuticals, hormones and bisphenol A in untreated source and finished drinking water in Ontario, Canada - Occurrence and treatment efficiency. Sci. Total Environ. 409(8):1481-88

Kolpin DW, Furlong ET, Meyer MT, Thurman EM. 2002. Pharmaceuticals, hormones, and other organic wastewater contaminants in U.S. streams, 1999-2000: a national reconnaissance. Environ. Sci. Technol. 36(6):1202-11

Laera G, Cassano D, Lopez A, Pinto A, Pollice A, et al. 2012. Removal of Organics and Degradation Products from Industrial Wastewater by a Membrane Bioreactor Integrated with Ozone or UV/ H 2 O 2 Treatment. Environ. Sci. Technol. 46:1010-18

Lim S-R, Park D, Park JM. 2008. Environmental and economic feasibility study of a total wastewater treatment network system. J. Environ. Manage. 88(3):564-75

Lofrano G. 2012. Emerging Compounds Removal from Wastewater, Natural and Solar Based Treatments. Salermo: Springer

Lyons G. 2014. Pharmaceuticals in the environment: A growing threat to our tap water and wildlife. London

Margot J, Kienle C, Magnet A, Weil M, Rossi L, et al. 2013. Treatment of micropollutants in municipal wastewater: 
Ozone or powdered activated carbon? Sci. Total Environ. 461-462:480-98

Melin T, Jefferson B, Bixio D, Thoeye C, De Wilde W, et al. 2006. Membrane bioreactor technology for wastewater treatment and reuse. Desalination. 187(1-3):271-82

Miller GW. 2006. Integrated concepts in water reuse: Managing global water needs. Desalination. 187(1-3):65-75

Muga HE, Mihelcic JR. 2008. Sustainability of wastewater treatment technologies. J. Environ. Manage. 88(3):437-47

Muñoz I. 2006. Life cycle assessment as a tool for green chemistry: application to different advanced oxidation processess for wastewater treatment. Universitat Autonoma de Barcelona

Muñoz I, Fernández-Alba AR. 2008. Reducing the environmental impacts of reverse osmosis desalination by using brackish groundwater resources. Water Res. 42(3):801-11

Muñoz I, Peral J, Antonio Ayllón J, Malato S, José Martin M, et al. 2007. Life-Cycle Assessment of a Coupled Advanced Oxidation-Biological Process for Wastewater Treatment: Comparison with Granular Activated Carbon Adsorption. Environ. Eng. Sci. 24(5):638-51

NRC. 2012. Water Reuse : Expanding the Nation's Water Supply Through Reuse of Municipal Wastewater. Washington DC

Onesios KM, Yu JT, Bouwer EJ. 2009. Biodegradation and removal of pharmaceuticals and personal care products in treatment systems: A review. Biodegradation. 20(4):441-66

Pasqualino JC, Meneses M, Abella M, Castells F. 2009. LCA as a decision support tool for the environmental improvement of the operation of a municipal wastewater treatment plant. Environ. Sci. Technol. 43(9):3300-3307

Pasqualino JC, Meneses M, Castells F. 2011. Life Cycle Assessment of Urban Wastewater Reclamation and Reuse Alternatives. J. Ind. Ecol. 15(1):49-63

Petala M, Tsiridis V, Samaras P, Zouboulis A, Sakellaropoulos GP. 2006. Wastewater reclamation by advanced treatment of secondary effluents. Desalination. 195(1-3):109-18

Quintana JB, Weiss S, Reemtsma T. 2005. Pathways and metabolites of microbial degradation of selected acidic pharmaceutical and their occurrence in municipal wastewater treated by a membrane bioreactor. Water Res. 39(12):2654-64

Ratola N, Cincinelli A, Alves A, Katsoyiannis A. 2012. Occurrence of organic microcontaminants in the wastewater treatment process. A mini review. J. Hazard. Mater. 239-240:1-18

Reed BE, Jamil M, Thomas B. 1996. Effect of pH, Empty Bed Contact Time and Hydraulic Loading Rate on Lead Removal by Granular Activated Carbon Columns. Water Environ. Res. 68(5):877-82

Reungoat J, Escher BI, Macova M, Keller J. 2011. Biofiltration of wastewater treatment plant effluent: Effective removal of pharmaceuticals and personal care products and reduction of toxicity. Water Res. 45(9):2751-62

Ribeiro AR, Nunes OC, Pereira MFR, Silva AMT. 2015. An overview on the advanced oxidation processes applied for the treatment of water pollutants defined in the recently launched Directive 2013/39/EU. Environ. Int. 75:33-51

Richardson BJ, Lam PKS, Martin M. 2005. Emerging chemicals of concern: Pharmaceuticals and personal care products (PPCPs) in Asia, with particular reference to Southern China. Mar. Pollut. Bull. 50(9):913-20

Rodriguez D, Van Buynder P, Lugg R, Blair P, Devine B, et al. 2009. Indirect potable reuse: A sustainable water supply alternative. Int. J. Environ. Res. Public Health. 6(3):1174-1209

Rosenbaum RK, Bachmann TM, Gold LS, Huijbregts M a J, Jolliet O, et al. 2008. USEtox - The UNEP-SETAC toxicity model: Recommended characterisation factors for human toxicity and freshwater ecotoxicity in life cycle impact assessment. Int. J. Life Cycle Assess. 13(7):532-46

Sala L, Serra M. 2004. Towards sustainability in water recycling. Water Sci. Technol. 50(2):1-8

Salgot M, Huertas E, Weber S, Dott W, Hollender J. 2006. Wastewater reuse and risk: Definition of key objectives. Desalination. 187(1-3):29-40

Schuman E. 2008. Fate of human pharmaceuticals in biological treatment systems treating concentrated wastewater under various environmental conditions. Wageningen University

Shannon M a, Bohn PW, Elimelech M, Georgiadis JG, Mariñas BJ, Mayes AM. 2008. Science and technology for water purification in the coming decades. Nature. 452(7185):301-10

Simon A, Price WE, Nghiem LD. 2013. Impact of chemical cleaning on the nanofiltration of pharmaceutically active compounds (PhACs): The role of cleaning temperature. J. Taiwan Inst. Chem. Eng. 44(5):713-23

Snyder S a., Adham S, Redding AM, Cannon FS, DeCarolis J, et al. 2007. Role of membranes and activated carbon in the removal of endocrine disruptors and pharmaceuticals. Desalination. 202(1-3):156-81

Suárez S, Carballa M, Omil F, Lema JM. 2008. How are pharmaceutical and personal care products (PPCPs) removed from urban wastewaters? Rev. Environ. Sci. Biotechnol. 7(2):125-38

Tabe S, Jamal T, Seth R, Yue C, Yang P, et al. 2009. PPCPs and EDCs - Occurrence in the Detroit River and Their Removal by Ozonation. Denver, USA

Tangsubkul N, Beavis P, Moore SJ, Lundie S, Waite TD. 2005. Life cycle assessment of water recycling technology. Water Resour. Manag. 19(5):521-37

Tarpani RRZ, Azapagic A. 2018. A methodology for estimating concentrations of pharmaceuticals and personal care products (PPCPs) in wastewater treatment plants and in freshwaters. Sci. Total Environ. 622-623:1417-30

Tchobanoglous G, Leverenz H, Nellor MH, Crook J. 2011. Direct Potable Reuse A Path Foward. Alexandria, VA 
ter Laak TL, van der Aa M, Houtman CJ, Stoks PG, van Wezel AP. 2010. Relating environmental concentrations of pharmaceuticals to consumption: A mass balance approach for the river Rhine. Environ. Int. 36(5):403-9

Ternes T a., Bonerz M, Herrmann N, Teiser B, Andersen HR. 2007. Irrigation of treated wastewater in Braunschweig, Germany: An option to remove pharmaceuticals and musk fragrances. Chemosphere. 66(5):894-904

Thinkstep. 2015. Gabi

Tripathi S, Tripathi BD. 2011. Efficiency of combined process of ozone and bio-filtration in the treatment of secondary effluent. Bioresour. Technol. 102(13):6850-56

Trovó AG, Silva TFS, Gomes O, Machado AEH, Neto WB, et al. 2013. Degradation of caffeine by photo-Fenton process: Optimization of treatment conditions using experimental design. Chemosphere. 90(2):170-75

Urkiaga A, De las Fuentes L, Bis B, Chiru E, Bodo B, et al. 2006. Methodologies for feasibility studies related to wastewater reclamation and reuse projects. Desalination. 187(1-3):263-69

Verlicchi P, Al Aukidy M, Zambello E. 2012. Occurrence of pharmaceutical compounds in urban wastewater: Removal, mass load and environmental risk after a secondary treatment-A review. Sci. Total Environ. 429:123-55

Wang L, Hung Y-T, Shammas N. 2005. Physicochemical Treatment Processes, Vol. 3. New Jersey: Humana Press Inc.

Webb S, Ternes T, Gibert M, Olejniczak K. 2003. Indirect human exposure to pharmaceuticals via drinking water. Toxicol. Lett. 142(3):157-67

Westerhoff P, Yoon Y, Snyder S, Wert E. 2005. Fate of endocrine-disruptor, pharmaceutical, and personal care product chemicals during simulated drinking water treatment processes. Environ. Sci. Technol. 39(17):6649-63

WHO. 2004. The World Medicines Situation. Geneva, CH

$\mathrm{Xu}$ J, Wu L, Chang AC. 2009. Degradation and adsorption of selected pharmaceuticals and personal care products (PPCPs) in agricultural soils. Chemosphere. 77(10):1299-1305

Yoon Y, Westerhoff P, Snyder S a., Wert EC. 2006. Nanofiltration and ultrafiltration of endocrine disrupting compounds, pharmaceuticals and personal care products. J. Memb. Sci. 270(1-2):88-100

Yoon Y, Westerhoff P, Snyder S a., Wert EC, Yoon J. 2007. Removal of endocrine disrupting compounds and pharmaceuticals by nanofiltration and ultrafiltration membranes. Desalination. 202(1-3):16-23

Yu Y, Liu Y, Wu L. 2013. Sorption and degradation of pharmaceuticals and personal care products (PPCPs) in soils. Environ. Sci. Pollut. Res. 20(6):4261-67

Yu Z, Peldszus S, Huck PM. 2008. Adsorption characteristics of selected pharmaceuticals and an endocrine disrupting compound-Naproxen, carbamazepine and nonylphenol-on activated carbon. Water Res. 42(12):2873-82 


\section{Life cycle environmental impacts of advanced wastewater treatment techniques for removal of compounds from pharmaceuticals and personal care products}

Raphael Ricardo Zepon Tarpani and Adisa Azapagic

\section{Supplementary information}

Table S1 - Operating data for granular activated carbon, nanofiltration and solar photo-Fenton considered in the study.

\begin{tabular}{|c|c|c|c|}
\hline & $\begin{array}{l}\text { Granular activated carbon } \\
\text { (Bonton et al. 2012) }\end{array}$ & $\begin{array}{l}\text { Nanofiltration } \\
\text { (Bonton et al. 2012) }\end{array}$ & $\begin{array}{l}\text { Solar photo-Fenton } \\
\text { (Muñoz 2006) }\end{array}$ \\
\hline Type & Modelled plant & Full-scale plant & Industrial-scale plant \\
\hline Location & Canada & Canada & Spain \\
\hline Influent flow & $2,000 \mathrm{~m}^{3} / \mathrm{d}$ & $2,000 \mathrm{~m}^{3} / \mathrm{d}$ & $6.8 \mathrm{~m}^{3} / \mathrm{d}$ \\
\hline Inhabitants & 3,140 & 3,140 & - \\
\hline Specifications & $\begin{array}{l}\text { Activated carbon density: } 500 \mathrm{~kg} / \mathrm{m}^{3} \\
\text { Carbon usage rate: } 0.076 \mathrm{~kg} / \mathrm{m}^{3} \\
\text { Current servicing time: } 91 \text { days } \\
\text { No regenerations } \\
\text { Pre-coagulation with Alum } \\
\text { Empty bed contact time: } 20 \mathrm{~min} \\
\text { Filtration rate: } 4.5 \mathrm{~m} / \mathrm{h}\end{array}$ & $\begin{array}{l}\text { Thin polyamide } \\
\text { membrane } \\
\text { Porous size: } 0.2 \mu \mathrm{m} \\
\text { Pressure applied: } 620 \\
\mathrm{kPa} \\
\text { Number of modules: } 270\end{array}$ & $\begin{array}{l}\text { Parabolic concentrators } \\
\text { UV radiation } \sim 30 \mathrm{~W} / \mathrm{m}^{2} \\
\text { Hydraulic retention time }>15 \\
\text { min } \\
\text { Panel surface area: } 4.16 \mathrm{~m}^{2} \\
\text { Borosilicate tubes } \\
\text { Tubes internal diameter: } 0.05 \mathrm{~m} \\
\text { Batch mode }\end{array}$ \\
\hline \multicolumn{4}{|c|}{ Influent characteristics } \\
\hline $\mathrm{pH}$ & 6.90 & 6.90 & - \\
\hline Total organic carbon (mg/L) & 9.70 & 9.70 & 20 \\
\hline Dissolved organic carbon (mg/L) & 9.20 & 9.20 & - \\
\hline Alkalinity $\left(\mathrm{mg} \mathrm{CaCO}_{3}\right) / \mathrm{L}$ & 6.50 & 6.50 & - \\
\hline Temperature $\left({ }^{\circ} \mathrm{C}\right)$ & 7.7 & 7.7 & 30 \\
\hline \multicolumn{4}{|c|}{ Effluent characteristics } \\
\hline $\mathrm{pH}$ & 7.5 & 7.5 & 3.0 \\
\hline Total organic carbon $(\mathrm{mg} / \mathrm{L})$ & 0.90 & 0.90 & - \\
\hline Dissolved organic carbon (mg/L) & 0.90 & 0.90 & - \\
\hline Alkalinity $\left(\mathrm{mg} \mathrm{CaCO}_{3}\right) / \mathrm{L}$ & 40.0 & 40.0 & - \\
\hline Temperature $\left({ }^{\circ} \mathrm{C}\right)$ & 8.0 & 8.0 & 30 \\
\hline
\end{tabular}

Table S2 - Spiral wound modules inventory modules (Bonton et al. 2012).

\begin{tabular}{lc}
\hline Spiral wound modules & Amount $\mathbf{( k g / 1 , 0 0 0 ~ \mathbf { ~ m } _ { \mathbf { 3 } } \text { ) }}$ \\
\hline Polyester resin, unsaturated, at plant & 0.14 \\
N,N-dimethylformamide at plant & 0.12 \\
Polyphenylene sulfide, at plant & 0.0014 \\
Polyvinyl chloride, at regional storage - permeate tube & 0.05 \\
Epoxy resin, liquid, at plant & 0.03 \\
Isopropanol, at plant & 0.017 \\
\hline
\end{tabular}


Table S3 - Freshwater ecotoxicity potential of effluents discharged to freshwaters for different removal efficiencies, estimated according to the USEtox methodology (Henderson et al. 2011).

\begin{tabular}{|c|c|c|c|c|c|c|c|c|c|c|c|c|c|c|c|c|c|c|}
\hline & \multicolumn{18}{|c|}{ 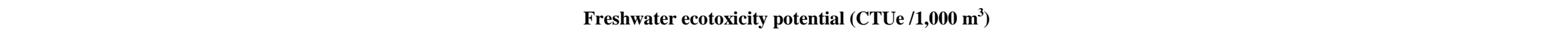 } \\
\hline & \multirow{2}{*}{\multicolumn{3}{|c|}{$\begin{array}{c}\text { Effluent without advanced } \\
\text { treatment }\end{array}$}} & \multicolumn{15}{|c|}{ Effluent with advanced treatment } \\
\hline & & & & \multicolumn{3}{|c|}{$65 \%$ removal } & \multicolumn{3}{|c|}{$75 \%$ removal } & \multicolumn{3}{|c|}{$85 \%$ removal } & \multicolumn{3}{|c|}{$95 \%$ removal } & \multicolumn{3}{|c|}{ 99\% removal } \\
\hline & Min & Mean & $\operatorname{Max}$ & Min & Mean & $\operatorname{Max}$ & Min & Mean & $\operatorname{Max}$ & $\operatorname{Min}$ & Mean & $\operatorname{Max}$ & Min & Mean & $\operatorname{Max}$ & Min & Mean & $\operatorname{Max}$ \\
\hline Diclofenac & 1.3083 & 1.7355 & 2.136 & 0.4579 & 0.6074 & 0.7476 & 0.3271 & 0.4339 & 0.534 & 0.1962 & 0.2603 & 0.3204 & 0.0654 & 0.0868 & 0.1068 & 0.0131 & 0.0174 & 0.0214 \\
\hline Ibuprofen & 0.0773 & 0.4159 & 0.7524 & 0.0271 & 0.1456 & 0.2633 & 0.0193 & 0.104 & 0.1881 & 0.0116 & 0.0624 & 0.1129 & 0.0039 & 0.0208 & 0.0376 & 0.0008 & 0.0042 & 0.0075 \\
\hline Trimethoprim & 0.0569 & 0.1138 & 0.1706 & 0.0199 & 0.0398 & 0.0597 & 0.0142 & 0.0284 & 0.0427 & 0.0085 & 0.0171 & 0.0256 & 0.0028 & 0.0057 & 0.0085 & 0.0006 & 0.0011 & 0.0017 \\
\hline Erythromycin & 18.177 & 18.675 & 19.173 & 6.362 & 6.5363 & 6.7106 & 4.5443 & 4.6688 & 4.7933 & 2.7266 & 2.8013 & 2.876 & 0.9089 & 0.9338 & 0.9587 & 0.1818 & 0.1868 & 0.1917 \\
\hline Sulfamethoxazole & 0.1794 & 0.5083 & 0.8372 & 0.0628 & 0.1779 & 0.293 & 0.0449 & 0.1271 & 0.2093 & 0.0269 & 0.0762 & 0.1256 & 0.009 & 0.0254 & 0.0419 & 0.0018 & 0.0051 & 0.0084 \\
\hline Carbamazepine & 0.8455 & 0.8711 & 0.8882 & 0.2959 & 0.3049 & 0.3109 & 0.2114 & 0.2178 & 0.222 & 0.1268 & 0.1307 & 0.1332 & 0.0423 & 0.0436 & 0.0444 & 0.0085 & 0.0087 & 0.0089 \\
\hline Estrone & 0.642 & 1.284 & 1.712 & 0.2247 & 0.4494 & 0.5992 & 0.1605 & 0.321 & 0.428 & 0.0963 & 0.1926 & 0.2568 & 0.0321 & 0.0642 & 0.0856 & 0.0064 & 0.0128 & 0.0171 \\
\hline $17 \beta$-Estradiol & 1472 & 1656 & 1840 & 515.2 & 579.6 & 644 & 368 & 414 & 460 & 220.8 & 248.4 & 276 & 73.6 & 82.8 & 92 & 14.72 & 16.56 & 18.4 \\
\hline Triclosan & 7.42 & 21.2 & 33.92 & 2.597 & 7.42 & 11.872 & 1.855 & 5.3 & 8.48 & 1.113 & 3.18 & 5.088 & 0.371 & 1.06 & 1.696 & 0.0742 & 0.212 & 0.3392 \\
\hline Total & $1,500.71$ & $1,700.80$ & $1,899.59$ & 525.25 & 595.281 & 664.86 & 375.18 & 425.20 & 474.897 & 225.11 & 255.12 & 284.94 & 75.035 & 85.04 & 94.98 & 15.01 & 17.01 & 18.996 \\
\hline
\end{tabular}

Table S4 - Freshwater ecotoxicity potentials of PPCPs in the effluents released to freshwaters and life cycle freshwater ecotoxicity potentials of advanced treatment options for different removal efficiencies, estimated according and to the USEtox methodology (Henderson et al. 2011).

\begin{tabular}{|c|c|c|c|c|c|c|c|c|c|c|c|c|c|c|c|}
\hline \multirow[b]{2}{*}{ Ecotoxicity $\left(\mathrm{CTU}_{\mathrm{e}} / \mathbf{1 0 0 0} \mathrm{m}^{\mathbf{3}}\right)$} & \multicolumn{3}{|c|}{$65 \%$ removal } & \multicolumn{3}{|c|}{$75 \%$ removal } & \multicolumn{3}{|c|}{$85 \%$ removal } & \multicolumn{3}{|c|}{$95 \%$ removal } & \multicolumn{3}{|c|}{$99 \%$ removal } \\
\hline & Min & Mean & $\operatorname{Max}$ & Min & Mean & $\operatorname{Max}$ & Min & Mean & $\operatorname{Max}$ & Min & Mean & $\operatorname{Max}$ & Min & Mean & $\operatorname{Max}$ \\
\hline PPCPs released to freshwaters & 525.25 & 595.28 & 664.86 & 375.18 & 425.20 & 474.90 & 225.11 & 255.12 & 284.94 & 75.04 & 85.04 & 94.98 & 15.01 & 17.01 & 19.00 \\
\hline Granular activated carbon (GAC) & 846.00 & $1,150.00$ & $1,710.00$ & 846.00 & $1,150.00$ & $1,710.00$ & 846.00 & $1,150.00$ & $1,710.00$ & 846.00 & $1,150.00$ & $1,710.00$ & 846.00 & $1,150.00$ & $1,710.00$ \\
\hline Nanofiltration (NF) & 386.00 & 474.00 & 562.00 & 386.00 & 474.00 & 562.00 & 386.00 & 474.00 & 562.00 & 386.00 & 474.00 & 562.00 & 386.00 & 474.00 & 562.00 \\
\hline Solar photo-Fenton (SPF) & $1,490.00$ & $2,960.00$ & $4,440.00$ & $1,490.00$ & $2,960.00$ & $4,440.00$ & $1,490.00$ & $2,960.00$ & $4,440.00$ & $1,490.00$ & $2,960.00$ & $4,440.00$ & $1,490.00$ & $2,960.00$ & $4,440.00$ \\
\hline Ozonation & 864.00 & $1,220.00$ & $1,550.00$ & 864.00 & $1,220.00$ & $1,550.00$ & 864.00 & $1,220.00$ & $1,550.00$ & 864.00 & $1,220.00$ & $1,550.00$ & 864.00 & $1,220.00$ & $1,550.00$ \\
\hline Total GAC & $1,371.25$ & $1,745.28$ & $2,374.86$ & $1,221.18$ & $1,575.20$ & $2,184.90$ & $1,071.11$ & $1,405.12$ & $1,994.94$ & 921.04 & $1,235.04$ & $1,804.98$ & 861.01 & $1,167.01$ & $1,729.00$ \\
\hline Total NF & 911.25 & $1,069.28$ & $1,226.86$ & 761.18 & 899.20 & $1,036.90$ & 611.11 & 729.12 & 846.94 & 461.04 & 559.04 & 656.98 & 401.01 & 491.01 & 581.00 \\
\hline Total SPF & $2,015.25$ & $3,555.28$ & $5,104.86$ & $1,865.18$ & $3,385.20$ & $4,914.90$ & $1,715.11$ & $3,215.12$ & $4,724.94$ & $1,565.04$ & $3,045.04$ & $4,534.98$ & $1,505.01$ & $2,977.01$ & $4,459.00$ \\
\hline Total Ozonation & $1,389.25$ & $1,815.28$ & $2,214.86$ & $1,239.18$ & $1,645.20$ & $2,024.90$ & $1,089.11$ & $1,475.12$ & $1,834.94$ & 939.04 & $1,305.04$ & $1,644.98$ & 879.01 & $1,237.01$ & $1,569.00$ \\
\hline
\end{tabular}


Table S5 - Freshwater ecotoxicity potential of effluents discharged to agricultural land for different removal efficiencies, estimated according to the USEtox methodology (Henderson et al. 2011).

\begin{tabular}{|c|c|c|c|c|c|c|c|c|c|c|c|c|c|c|c|c|c|c|}
\hline & \multicolumn{18}{|c|}{ Freshwater ecotoxicity potential (CTUe /1,000 m³) } \\
\hline & \multirow{2}{*}{\multicolumn{3}{|c|}{$\begin{array}{l}\text { Effluent without advanced } \\
\text { treatment }\end{array}$}} & \multicolumn{15}{|c|}{ Effluent with advanced treatment } \\
\hline & & & & \multicolumn{3}{|c|}{$65 \%$ removal } & \multicolumn{3}{|c|}{$75 \%$ removal } & \multicolumn{3}{|c|}{$85 \%$ removal } & \multicolumn{3}{|c|}{$95 \%$ removal } & \multicolumn{3}{|c|}{ 99\% removal } \\
\hline & Min & Mean & $\operatorname{Max}$ & $\operatorname{Min}$ & Mean & $\operatorname{Max}$ & $\operatorname{Min}$ & Mean & $\operatorname{Max}$ & $\operatorname{Min}$ & Mean & $\operatorname{Max}$ & Min & Mean & $\operatorname{Max}$ & $\operatorname{Min}$ & Mean & $\operatorname{Max}$ \\
\hline Diclofenac & 0.0515 & 0.0683 & 0.084 & 0.018 & 0.0239 & 0.0294 & 0.0129 & 0.0171 & 0.021 & 0.0077 & 0.0102 & 0.0126 & 0.0026 & 0.0034 & 0.0042 & 0.0005 & 0.0007 & 0.0008 \\
\hline Ibuprofen & 0.0014 & 0.0073 & 0.0132 & 0.0005 & 0.0026 & 0.0046 & 0.0003 & 0.0018 & 0.0033 & 0.0002 & 0.0011 & 0.002 & 0.0001 & 0.0004 & 0.0007 & 0 & 0.0001 & 0.0001 \\
\hline Trimethoprim & 0.0023 & 0.0046 & 0.0069 & 0.0008 & 0.0016 & 0.0024 & 0.0006 & 0.0012 & 0.0017 & 0.0003 & 0.0007 & 0.001 & 0.0001 & 0.0002 & 0.0003 & 0 & 0 & 0.0001 \\
\hline Erythromycin & 2.2776 & 2.34 & 2.4024 & 0.7972 & 0.819 & 0.8408 & 0.5694 & 0.585 & 0.6006 & 0.3416 & 0.351 & 0.3604 & 0.1139 & 0.117 & 0.1201 & 0.0228 & 0.0234 & 0.024 \\
\hline Sulfamethoxazole & 0.0117 & 0.0332 & 0.0546 & 0.0041 & 0.0116 & 0.0191 & 0.0029 & 0.0083 & 0.0137 & 0.0018 & 0.005 & 0.0082 & 0.0006 & 0.0017 & 0.0027 & 0.0001 & 0.0003 & 0.0005 \\
\hline Carbamazepine & 0.0124 & 0.0128 & 0.013 & 0.0043 & 0.0045 & 0.0046 & 0.0031 & 0.0032 & 0.0033 & 0.0019 & 0.0019 & 0.002 & 0.0006 & 0.0006 & 0.0007 & 0.0001 & 0.0001 & 0.0001 \\
\hline Estrone & 0.0006 & 0.0012 & 0.0015 & 0.0002 & 0.0004 & 0.0005 & 0.0001 & 0.0003 & 0.0004 & 0.0001 & 0.0002 & 0.0002 & 0 & 0.0001 & 0.0001 & 0 & 0 & 0 \\
\hline 17ß-Estradiol & 2.04 & 2.295 & 2.55 & 0.714 & 0.8033 & 0.8925 & 0.51 & 0.5738 & 0.6375 & 0.306 & 0.3443 & 0.3825 & 0.102 & 0.1148 & 0.1275 & 0.0204 & 0.023 & 0.0255 \\
\hline Triclosan & 0.014 & 0.04 & 0.064 & 0.0049 & 0.014 & 0.0224 & 0.0035 & 0.01 & 0.016 & 0.0021 & 0.006 & 0.0096 & 0.0007 & 0.002 & 0.0032 & 0.0001 & 0.0004 & 0.0006 \\
\hline Total & 4.41 & 4.80 & 5.19 & 1.54 & 1.68 & 1.82 & 1.10 & 1.20 & 1.297 & 0.66 & 0.72 & 0.78 & 0.22 & 0.24 & 0.26 & 0.044 & 0.05 & 0.05 \\
\hline
\end{tabular}

Table S6 - Freshwater ecotoxicity potentials of PPCPs in the effluents released to agricultural land and life cycle freshwater ecotoxicity potentials of advanced treatment options for different removal efficiencies, estimated according to the USEtox methodology (Henderson et al. 2011).

\begin{tabular}{|c|c|c|c|c|c|c|c|c|c|c|c|c|c|c|c|}
\hline \multirow[b]{2}{*}{ Ecotoxicity $\left(\mathrm{CTU}_{\mathrm{e}} / \mathbf{1 0 0 0} \mathrm{m}^{3}\right)$} & \multicolumn{3}{|c|}{$65 \%$ removal } & \multicolumn{3}{|c|}{$75 \%$ removal } & \multicolumn{3}{|c|}{$85 \%$ removal } & \multicolumn{3}{|c|}{$95 \%$ removal } & \multicolumn{3}{|c|}{$99 \%$ removal } \\
\hline & Min & Mean & $\operatorname{Max}$ & $\operatorname{Min}$ & Mean & $\operatorname{Max}$ & Min & Mean & $\operatorname{Max}$ & Min & Mean & $\operatorname{Max}$ & Min & Mean & $\operatorname{Max}$ \\
\hline PPCPs released to agric. land & 1.5440 & 1.6808 & 1.8164 & 1.1028 & 1.2006 & 1.2974 & 0.6617 & 0.7203 & 0.7785 & 0.2206 & 0.2401 & 0.2595 & 0.0441 & 0.0480 & 0.0519 \\
\hline Granular activated carbon (GAC) & 846.00 & $1,150.00$ & $1,710.00$ & 846.00 & $1,150.00$ & $1,710.00$ & 846.00 & $1,150.00$ & $1,710.00$ & 846.00 & $1,150.00$ & $1,710.00$ & 846.00 & $1,150.00$ & $1,710.00$ \\
\hline Nanofiltration (NF) & 386.00 & 474.00 & 562.00 & 386.00 & 474.00 & 562.00 & 386.00 & 474.00 & 562.00 & 386.00 & 474.00 & 562.00 & 386.00 & 474.00 & 562.00 \\
\hline Solar photo-Fenton (SPF) & $1,490.00$ & $2,960.00$ & $4,440.00$ & $1,490.00$ & $2,960.00$ & $4,440.00$ & $1,490.00$ & $2,960.00$ & $4,440.00$ & $1,490.00$ & $2,960.00$ & $4,440.00$ & $1,490.00$ & $2,960.00$ & $4,440.00$ \\
\hline Ozonation & 864.00 & $1,220.00$ & $1,550.00$ & 864.00 & $1,220.00$ & $1,550.00$ & 864.00 & $1,220.00$ & $1,550.00$ & 864.00 & $1,220.00$ & $1,550.00$ & 864.00 & $1,220.00$ & $1,550.00$ \\
\hline Total GAC & 847.54 & $1,151.68$ & $1,711.82$ & 847.10 & $1,151.20$ & $1,711.30$ & 846.66 & $1,150.72$ & $1,710.78$ & 846.22 & $1,150.24$ & $1,710.26$ & 846.04 & $1,150.05$ & $1,710.05$ \\
\hline Total NF & 387.54 & 475.68 & 563.82 & 387.10 & 475.20 & 563.30 & 386.66 & 474.72 & 562.78 & 386.22 & 474.24 & 562.26 & 386.04 & 474.05 & 562.05 \\
\hline Total SPF & $1,491.54$ & $2,961.68$ & $4,441.82$ & $1,491.10$ & $2,961.20$ & $4,441.30$ & $1,490.66$ & $2,960.72$ & $4,440.78$ & $1,490.22$ & $2,960.24$ & $4,440.26$ & $1,490.04$ & $2,960.05$ & $4,440.05$ \\
\hline Total Ozonation & 865.54 & $1,221.68$ & $1,551.82$ & 865.10 & $1,221.20$ & $1,551.30$ & 864.66 & $1,220.72$ & $1,550.78$ & 864.22 & $1,220.24$ & $1,550.26$ & 864.04 & $1,220.05$ & $1,550.05$ \\
\hline
\end{tabular}




\section{References}

Bonton A, Bouchard C, Barbeau B, Jedrzejak S. 2012. Comparative life cycle assessment of water treatment plants. Desalination. 284:42-54.

Henderson AD, Hauschild MZ, Van De Meent D, Huijbregts M a J, Larsen HF, et al. 2011. USEtox fate and ecotoxicity factors for comparative assessment of toxic emissions in life cycle analysis: Sensitivity to key chemical properties. Int. J. Life Cycle Assess. 16(8):701-9.

Muñoz I. 2006. Life cycle assessment as a tool for green chemistry: application to different advanced oxidation processess for wastewater treatment. Universitat Autonoma de Barcelona.

Rosenbaum RK, Bachmann TM, Gold LS, Huijbregts M a J, Jolliet O, et al. 2008. USEtox The UNEP-SETAC toxicity model: Recommended characterisation factors for human toxicity and freshwater ecotoxicity in life cycle impact assessment. Int. J. Life Cycle Assess. 13(7):532-46. 